\title{
Krzysztof Ozga*
}

iD https://orcid.org/0000-0002-5633-8954

\section{Tajemnice ASMR - perspektywa ogólna i lingwistyczna'}

\section{Definitcja pojęcia i stan badań}

ASMR to skrótowiec, który rozszyfrowuje się jako Autonomous Sensory Meridian Response; w tłumaczeniu polskim: samoistna odpowiedź meridianów czuciowych. Barratt i Davis (2015: Abstract) opisują ASMR na podstawie relacji osób, które go doświadczają, jako zjawisko sensoryczne, polegające na odczuwaniu mrowienia (ang. tingles) ${ }^{2} \mathrm{w}$ okolicach skóry głowy, karku, a także sporadycznie na innych obszarach ciała w odpowiedzi na określone bodźce słuchowe i wzrokowe, któremu towarzyszy uczucie odprężenia i dobrego samopoczucia ${ }^{3}$. Określenie meridiany pochodzi z medy-

* Dr, Uniwersytet Jagielloński, Instytut Filologii Wschodniosłowiańskiej; e-mail: kozga.uj@ gmail.com

1 Ponieważ na gruncie polskim nie ukazała się do tej pory żadna publikacja poświęcona zjawisku ASMR, artykuł zawiera uwagi zarówno natury ogólnej - wyjaśniające, czym jest owo zjawisko, jakie są jego źródła i jednocześnie poszerzające perspektywę opisu dostępnego w publikacjach zagranicznych, jak i natury lingwistycznej w zakresie przede wszystkim fonetyki, onomastyki i analizy dyskursu.

2 Wśród polskiej społeczności ASMR mrowienie to jest zwykle nazywane „ciarkami”.

$3 \mathrm{Na}$ jednym z forów internetowych, którego użytkownicy próbowali określić to, czego doświadczają, kiedy jeszcze termin ASMR nie został stworzony, jeden z uczestników napisał: "Chyba wiem, o czym mówisz. Szukałem odpowiedzi na podobne pytanie, kiedy znalazłem Twój post. Od dzieciństwa miewam takie dziwne uczucie w głowie. Odkryłem, że dzieje się to wtedy, kiedy pewne osoby do mnie mówią, szczególnie, kiedy mówią powoli, lub kiedy ludzie poruszają się powoli, lub nawet powoli prowadzą samochód... To takie mrowienie (tingling) na skórze głowy. Jedyny sposób, w jaki mogę to opisać, to coś jak srebrzysta iskra przenikająca moja głowę i mózg... prawie jak coś w rodzaju orgazmu głowy, ale nie ma to nic wspólnego z doznaniami seksualnymi... Co to jest? Czy to to samo uczucie, które Ty opisujesz?" (Smith, Snider 2019: 44, tłum. moje, K. O.). 
cyny chińskiej. Redaktor pracy J. Needhama et al. (2004: 48), Ch. Cullen, wyjaśnia, że użycie terminu meridian w obecnym znaczeniu zawdzięczamy dziewiętnastowiecznym europejskim akupunkturzystom, którzy oryginalne słowo ching ${ }^{4}$, oznaczające trakty czy też aku-trakty (ang. tracts or acu-trackts), wzdłuż których rozmieszczone są punkty akupunkturowe, tłumaczyli jako meridian poprzez błędną analogię do innego znaczenia ching, czyli długości geograficznej. Owo geograficzne znaczenie funkcjonuje zresztą we współczesnej angielszczyźnie, bowiem angielskie słowo meridian to przede wszystkim południk, czyli linia łącząca bieguny geograficzne. W tym kontekście możemy sobie wyobrazić tzw. efekt ASMR jako odpowiedź organizmu ludzkiego na pewne bodźce zmysłowe, opisywaną jako mrowienie („ciarki”), która przebiega w określonych punktach czuciowych umiejscowionych na liniach, zwanych przez autorkę terminu ASMR - Jennifer Allen ${ }^{5}$ - meridianami. Znaczenie terminu meridian nie jest tutaj rzecz jasna tożsame ze znaczeniem stosowanym w medycynie chińskiej. Termin ów wydaje się być wszakże zrozumiałą analogią.

Owa odpowiedź sensoryczna dotyczy jedynie pewnej grupy ludzi. Barratt i Davis przeprowadzili badanie ankietowe na grupie osób, które twierdzą, iż doświadczają efektu ASMR. Analiza pokazała, że 98\% uczestników korzysta z ASMR w celach relaksacyjnych, $82 \%$ deklaruje, że ASMR pomaga im zasnąć, a $70 \%$ ankietowanych ASMR pomaga radzić sobie ze stresem (Barratt, Davis 2015: Results). Mimo, iż badania te zostały przeprowadzone na jednostkach, które doświadczają ASMR, ich rezultaty pozwalają wyjaśnić, dlaczego społeczność ASMR obfituje w wiele osób, które efektu ASMR nie doświadczają, bowiem subskrybenci kanałów ASMR wykorzystują filmy ASMR w tych samych celach, co jednostki owego efektu doświadczające, czyli do relaksacji, pomocy w radzeniu sobie z bezsennością, czy też ze stresem.

Autorzy artykułu twierdzą, że do chwili powstania ich tekstu nie spotkali się z "rzetelnym naukowym opracowaniem ASMR oraz uwarunkowań wywołujących czy też kończących stan ASMR” (Barratt i Davis 2015: Introduction, tłum moje, K. O.) $)^{6}$. Środowisko naukowe niejednokrotnie poddawało w wątpliwość występowanie tego zjawiska. Steven Novella, neurolog kliniczny z Yale University School of Medicine, zaangażowany w ruch sceptycyzmu naukowego w 2012 roku napisał na NEUROLOGICAblog, iż ASMR ,jest bodajże kolejnym zjawiskiem (...), które

4 Por. rozróżnienie ching (trakty) i sui oznaczające kanały (ang. conduits), Needham et al. (2004: 48, przypis redaktora wydania).

5 Jennifer Allen deklaruje, iż stworzyła termin ASMR w 2010 roku, https://asmruniversity. com/2016/05/17/jennifer-allen-interview-coined-asmr/

6 Dwalata wcześniej ukazał sięartykułnawiązujący do filmów ASMR, wktórych wykorzystywane jest tzw. odgrywanie roli, a konkretnie roli lekarza (badanie lekarskie) jako punkt odniesienia do analizy przystawalności tego zjawiska do diagnostyki klinicznej w świetle tekstu Love in the Ruins (1971) Walkera Percy'ego - lekarza-pisarza. Artykuł ów nie stanowi wszakże badania zjawiska ASMR per se (Nitin K. Ahuja 2013: 442-451). 
Internet przenosi ze sfery do tej pory osobistych i ukrytych doświadczeń do świadomości ogółu (...), nadając mu nazwę i pozostawiając ślad internetowy. Oczywiście takie zjawiska nie zawsze są realne - czasami z Internetu wyłania się schemat prawdziwy, a czasem schematy iluzoryczne lub błędnie identyfikowane, będące kulturowym odpowiednikiem pareidolii"7.

Artykuł Barratt i Davisa (2015) nie dowodzi stricte istnienia efektu ASMR, bowiem bazuje na metodzie ankietowej, zgodnie z którą wyniki badań oparte są na deklarowanych odczuciach ankietowanych. Jednakże w ostatnich latach ukazały się artykuły, które potwierdzają występowanie zjawiska poprzez obserwację aktywności mózgu w momencie ekspozycji na wyzwalacze ASMR za pomocą funkcjonalnego obrazowania metodą rezonansu magnetycznego. Metoda ta pokazuje, że obszary mózgu aktywowane $\mathrm{w}$ danej sytuacji mają większe zapotrzebowanie na tlen. Wzrost aktywności danego obszaru mózgu mierzony jest poprzez efekt $\mathrm{BOLD}$ ( $\mathrm{z}$ ang. blood oxygen level dependent). „Należy (...) podkreślić, że wzrost aktywności nerwowej w danym obszarze mózgu powoduje nasilenie przepływu krwi przez tę okolicę, któremu jednak nie towarzyszy proporcjonalnie zwiększone zużycie tlenu przez tkankę. W efekcie w pobudzonych obszarach znajduje się nieco więcej oksyhemoglobiny, będącej właśnie źródłem silniejszego sygnału" (Gut, Marchewka 2004: 36). Pierwszy z artykułów kontrastował grupy osób doświadczających ASMR z grupą kontrolną poprzez obserwację DMN (default mode network, pol. sieć standardowej aktywności mózgu / sieć stanu spoczynkowego / sieć aktywności bazowej / sieć wzbudzeń podstawowych). Badanie pokazało, że DMN osób z ASMR wykazywała znacznie mniej połączeń funkcjonalnych niż w grupie kontrolnej, a także zwiększoną ilość połączeń pomiędzy korami potylicznym, czołowymi i skroniowymi, co sugeruje, iż ASMR związane jest z kontaminacją wielu sieci stanu spoczynkowego (Smith, Fredborg, Kornelsen 2017: 361). Celem drugiego artykułu była obserwacja aktywności mózgu osób poddanych wstępnej ocenie wrażliwości na ASMR podczas oglądania filmów ASMR w momentach, w których deklarowały one szczególne doznania mrowienia i relaksacji. Rezultaty badań pokazały, że w chwilach doświadczania ASMR u pacjentów obserwowana była znacząca aktywność w regionach związanych zarówno z ośrodkiem nagrody (jądro półleżące), jak i pobudzeniem emocjonalnym (obszar grzbietowy zakrętu obręczy kory mózgowej i wyspa / zakręt czołowy dolny). Aktywacja mózgu podczas ASMR wykazała podobieństwa do schematów obserwowanych uprzednio w dreszczach muzycznych (ang. musical frisson) oraz zachowaniach afiliacyjnych (Lochte, Guillory, Richard, Kelley 2018: 295). Na podstawie owych dociekań, a także innych opublikowanych badań ${ }^{8}$ można zatem przyjąć, iż efekt ASMR istnieje, mimo iż nie wszyscy ludzie mogą go doświadczać.

7 https://theness.com/neurologicablog/index.php/asmr, tłum. moje, K. O. [data dostępu: 20.04.2018].

8 Od roku 2017 powstało ponad 20 recenzowanych prac z zakresu medycyny, psychologii, neurobiologii i socjologii, badających ASMR z różnych perspektyw, np. korelacja z cechami 


\section{Wyzwalacze}

\subsection{Definicja i klasyfikacja}

Wyzwalacze ( $\mathrm{z}$ ang. triggers) to bodźce wywołujące efekt ASMR. Cytowany powyżej artykuł Barratt i Davisa (2015) wymienia dwa typy bodźców: wzrokowe i słuchowe. Proponuję jednak poszerzyć ich zakres o bodźce związane z dwoma z pozostałych pięciu podstawowych zmysłów. Ich bazową klasyfikację można przedstawić za pomocą wykresu:

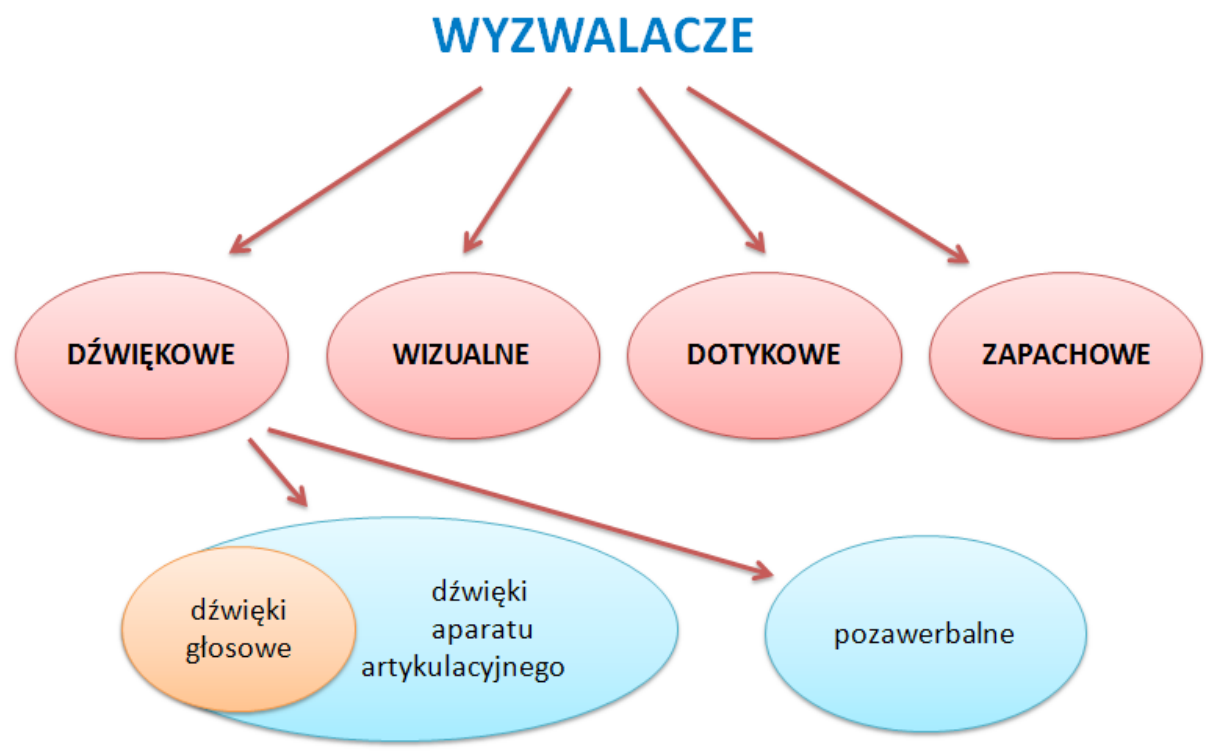

Ryc. 1. Wyzwalacze ASMR. Źródło: opracowanie własne.

Barratt i Davis (2015) nie uwzględniają dotyku i zapachu jako sfer, w których może zachodzić efekt ASMR, bowiem media, poprzez które odbiorcy doświadczają kontaktu z artystami ASMR', to współczesne odbiorniki filmów - komputer,

osobowości oraz empatią (Fredborg, Clark, Smith 2017; Janik McErlean, Banissy 2017), odpornością na stres (Williams, Johnson, Curtis, King, Anderson 2018: 156-165), terapią audiowizualną (Garro 2017: 395-402), efektem placebo (Ahuja, Ahuja 2019), intymnością w kontakcie warunkowanym technologicznie (Smith, Snider 2019: 41-48), etc. Powstał nawet przewodnik po ASMR napisany przez profesora fizjologii i biologii komórkowej (Richard 2018). Nie spotkałem się jednakże z opracowaniami ASMR z perspektywy lingwistycznej.

9 Twórcy filmików ASMR zwani są przez społeczność ASMR (ang. ASMR community) artystami ASMR (ang. ASMRtists - nazwa w języku angielskim stanowi blend poprzez nałożenie wygłosu i nagłosu leksemów ASMR i artist). 
smartfon, tablet, itd. ${ }^{10}$ (por. Smith, Snider 2019). Ograniczeniem owych mediów jest fakt, iż uniemożliwiają one odczucia zmysłowe w zakresie dotyku i zapachu bezpośrednio. Istnieją jednakże argumenty przemawiające za włączeniem dotyku i zapachu w gamę bodźców ASMR.

Po pierwsze, filmy ASMR bardzo często wykorzystują zjawisko synestezji, czyli sytuacji, w której ,jednomodalny bodziec zmysłowy wywołuje mimowolnie jednoczesne wrażenie $\mathrm{w}$ dwu lub więcej modalnościach zmysłowych" (Rogowska 2002: 465). Twórca filmu używa obiektu generującego zapach i przez jego wizualizację i opis oddziałuje na odbiorcę, np. Little Clover Whispers w filmiku "ASMR Lighting Candles \& Incense Sticks"11 zapala i pokazuje kadzidełka, a Isabel Imagination ASMR w filmiku „ASMR Aroma Therapy Session”12 rozpyla zapach na wachlarzu, a następnie wachluje w stronę odbiorcy.

Po drugie, artyści ASMR usiłują wywołać u odbiorców efekt ASMR indirecto. W przypadku zapachu najczęściej sami na ekranie odbierają sygnały węchowe, a zadaniem odbiorcy jest wyobrażenie sobie percepcji woni. W przypadku dotyku, artyści zapraszają do współpracy przy tworzeniu filmu inne osoby i na przykład wykonują masaż na tych osobach jako na pacjentach. Towarzyszą temu rzecz jasna dźwięki, a bardzo często także opis wykonywanych czynności; czyni to np. artystka itsblitzzz w filmie „ASMR Head massage and energy healing on a new friend (soft spoken)"13

Po trzecie, mimo ukonstytuowania się terminu dopiero w 2010 roku poprzez popularyzację zjawiska w Internecie, można przypuszczać, iż doświadczanie mrowienia na meridianach czuciowych nie jest niczym nowym. W dobie przedinternetowej występowało ono (i nadal występuje) w bezpośrednim kontakcie z drugim człowiekiem, zatem nie wymagało synestezji, a podstawowymi bodźcami obok werbalnych i wizualnych, były przede wszystkim bodźce dotykowe. Pewnie niejedna osoba pamięta z własnego dzieciństwa ${ }^{14}$ zabawy, w których rodzice dzieciom

10 Por. digitally-mediated intimacy (Smith, Snider 2019: 41).

11 https://www.youtube.com/watch?v=HNBSJohzcno [data dostępu: 11.04.2019].

12 https://www.youtube.com/watch?v=RDWKdgzYzsE [data dostępu: 5.06 .2018 ].

13 https://www.youtube.com/watch?v=julm2C5OWW4 [data dostępu: 8.10.2018].

14 Inni badacze, poszukujący źródeł ASMR również wskazują na relacje osób, które z dzieciństwa pamiętają uczucie mrowienia, np. Smith, Snider (2019: 44) cytują wpis z forum, poświęconego identyfikacji zjawiska, określonego obecnie jako ASMR: "I get this sensation sometimes. Theres [sic] no real trigger for it. It just happenes [sic] randomly...some examples of what it seems has caused it to happen before are as a child while watching a puppet show and when i was being read a story to. as a teenager when a classmate did me a favor and when a friend drew on the palm of my hand with markers (podkreślenie moje, K.O.). sometimes it happens for no reason at all that i can tell...". Tu również pojawia się doświadczenie ASMR poprzez zmysł dotyku (vide podkreślony fragment cytatu). 
lub dzieci sobie nawzajem „pisali/ły” po plecach, recytując wierszyki, które opisywały wykonywane przez nich palpacyjnie czynności, np.

Pisała pisarka na maszynie (udajemy pisanie na maszynie palcami na plecach) przeszła pani na szpileczkach (idziemy w górę pleców dwoma palcami na zmianę) płynie sobie kręta rzeka (wykonujemy slalom wierzchołkiem dłoni w górę pleców) ida stonie (pomału piąstkami - raz jedna raz druga - idziemy w górę pleców) biegna konie po betonie (intensywniej i szybciej uderzamy knykciami) pada deszczyk (opuszkami palców stukamy po plecach w różnych miejscach) czujesz dreszczyk? (łaskoczemy kciukiem i środkowym palcem kark po lewej i prawej stronie)

Ostanie pytanie w wierszyku stanowi bezpośrednią werbalizacją odczuć opisywanych obecnie jako efekt ASMR. Podobnego typu twz. wierszyki-masażyki pojawiają się bardzo często na współczesnych blogach parentingowych (blogach poświęconych świadomemu rodzicielstwu ${ }^{15}$.

Ponadto na blogach dedykowanych ASMR znaleźć można wpisy osób, które deklarują odczuwanie mrowienia na skutek bodźców zapachowych, np. DanaG214 pisze: „Doświadczam tego, kiedy moja koleżanka z pracy stosuje balsam od Bath and Body Works, a także od zapachu jej perfum"16 (tłum moje, K. O.), a na innym forum użytkownik Tim $K$ twierdzi: "Zauważyłem podobne opisy [ASMR] w innych miejscach i wydaje się, że ZAPACH jest w nich zawsze pomijany. Dla mnie (a także dla innych osób, z którymi rozmawiałem o ASMR) zapach jest BARDZO silnym wyzwalaczem. Czasem zapach cygara/fajki/papierosa $z$ oddali lub sąsiedniego samochodu, a czasem czyjeś perfumy lub woda po goleniu same w sobie wyzwalają ciarki"17 (tłum moje, K. O.).

Nie pojawiają się natomiast żadne relacje o bodźcach smakowych, dlatego smak jako wyzwalacz ASMR nie został uwzględniony w klasyfikacji, co rzecz jasna nie wyklucza możliwości doświadczania przez niektóre osoby efektu ASMR w zakresie tego zmysłu. Powstają nagrania ASMR dotyczące smaku, np. The French Whisperer przedstawia film o degustacji wina: "ASMR - Wine Tasting (for dummies)

15 Na przykład: http://wronek.pl/nasze-ulubione-wierszyki-masazyki; https://polki.pl/rodzina/ rozmowy,zabawy-na-plecach-dziecka-quot-plynie-rzeczka-idzie-pani-na-szpileczkach-quotkto-pamieta,978790,1,wypowiedzi.html; http://www.zabawydladzieci.com.pl/masazyki.

W ostatnich latach podkreślane są walory terapeutyczne a także socjalizujące komunikacji przez dotyk, por. Ch. Knill (2009).

$16 \mathrm{https} / / / \mathrm{www}$. reddit.com/r/asmr/comments/46ck1v/question_has_anyone_experienced_ asmr_through_smell [data dostępu: 29.04.2019].

17 https://www.asmrtingles.com/what-is-asmr [data dostępu: 5.05.2019]. 
- Show And Tell”18. Jednak smak stanowi tutaj wartość tematyczną nagrania, a głównymi wyzwalaczami są bodźce werbalne i wizualne, co zresztą potwierdza treść komentarzy odbiorców.

\subsection{Dźwięki aparatu artykulacyjnego}

\subsubsection{Dźwięki głosowe}

Mimo powyższych argumentów w świecie ASMR, funkcjonującym przede wszystkim w przestrzeni internetowej, podstawowymi wyzwalaczami pozostają te ze sfery dźwiękowej i wizualnej. Przyjrzyjmy się im nieco bardziej szczegółowo. Zacznijmy od dźwięków głosowych. W ich obrębie znajdujemy całą gamę bodźców wyzwalanych przez mowę, której stopnie wyodrębniane są nie tylko ze względu na skalę głośności dźwięków aparatu artykulacyjnego, ale przed wszystkim ze względu na udział wiązadeł głosowych ${ }^{19} \mathrm{~W}$ ich produkcji, czyli od szeptu do pełnego głosu ${ }^{20}$ :

- niesłyszalny/niezrozumiały szept (ang. inuadible/untintelligible whisper)

- na wpół słyszalny szept (ang. semi-inaudible whisper)

- delikatny szept (ang. soft whisper)

- delikatny głos, półgłos (ang. softly spoken)

- głos / [film] mówiony (ang. spoken)

Bardzo ciekawym wyzwalaczem jest pierwszy $\mathrm{z}$ wymienionych, bowiem wśród samych artystów ASMR funkcjonują dwa zasadnicze podejścia do tego bodźca ${ }^{21}$. Jedni ${ }^{22}$ utożsamiają pojęcia inaudible (niesłyszalny) i untintelligible (niezrozumiały) i rozumieją oba jako typ szeptu, z którego jesteśmy w stanie usłyszeć jedynie pojedyncze segmenty lub klastery zgłoskowe w wyniku czego bądź nie rozumiemy całości przekazu, bądź rozumiemy go dzięki ośrodkowi Wernickego, odpowiedzialnemu za rozumienie języka pisanego i mówionego, którego funkcje pozwalają na uzupełnienie nieusłyszanych ciągów fonicznych

18 https://www.youtube.com/watch?v=evPXPSYy1Do [data dostępu: 6.05.2019].

19 Por. tony vs. szumy, dźwięczne vs. bezdźwięczne, półotwarte vs. obstruenty (Wiśniewski 2001: 38, 40, 42).

20 W nawiasach zwykle podaję wariant angielski, ponieważ wyzwalacze zarówno w filmach i ich deskrypcjach, jak i na forach dostępne są przede wszystkim w języku angielskim. Niektóre z nich są tłumaczone na polskich kanałach ASMR, jednak przekładu wielu z nich musiałem dokonać samodzielnie.

21 Por. dyskusje na ten temat na forach ASMR, np. https://www.reddit.com/r/asmr/ comments/6ujieg/lets_settle_this_once_and_for_all_unintelligible [data dostępu: 4.05.2019].

22 np. WhisperAudios ASMR, https://www.youtube.com/watch?v=--ryaNH6OwM [data dostępu: 18.01.2019]. 
i leksykalnych (por. Harpaz, Levkovitz, Lavidor 2009: 1097-1103)23. Z kolei inni artyści ${ }^{24}$ stawiają wyraźną granicę pomiędzy tymi pojęciami i niesłyszalny szept definiują jak powyżej z zaznaczeniem, że winien on być produkowany $w$ istniejącym żywym języku, a wariant niezrozumiały to szept będący artykulacją zbitek głoskowych nie tworzących sensu.

Oprócz wyżej wymienionych wyzwalacze w zakresie dźwięków głosowych charakteryzowane są czynnikami suprasegmentalnymi - mowa monotonna (ang. monotone) i iteratywnymi. Do tej drugiej kategorii należą zarówno reduplikacje leksykalne (tzw. trigger words), polegające na tym, że artysta powtarza przez pewien czas dane słowo-wyzwalacz, czyli wyraz, który zawiera określone zbitki głoskowe, np. tingles tingles, tingles, tingles..., jak i reduplikacje izolowanych klasterów głoskowych, często o charakterze onomatopei, np. sk-sk..., tk-tk.., shooop-shooop, nom-nom, typ-typ, typy-typy. Niejednokrotnie towarzyszą temu bodźce wizualne, np. powtarzanie sylaby dźwiękonaśladowczej typ-typ-..., przy jednoczesnej symulacji nakładania słuchaczowi kremu na twarz opuszkami palców (SoftAnnaPL w filmie "ASMR - Make Up Artist Role Play + Whisper and Soft Spoken in Polish").

\subsubsection{Pozostałe dźwięki aparatu artykulacyjnego}

Obok dźwięków mowy popularne są także inne dźwięki aparatu artykulacyjnego:

- klikanie językiem (ang. tongue clicking)

- całowanie

- mlaskanie, dosłownie: dźwięki mokrych ust (ang. wet mouth sounds)

- żucie

- ssanie cukierków

- cmokanie (ang. lip smacking)

Mogą one być produkowane samodzielnie bądź w kombinacji z dźwiękami głosowymi, np. szepty z dźwiękami mokrych ust/mlaskaniem (ang. wet mouth sound whispering)

23 Owe uzupełnienia foniczne warunkowane są semantyką. Por. przykład A.C. Gimsona: „...in any discussion about a zoo, involving a statement such as 'We saw the lions and tigers', we are predisposed by the context to understand lions, even if the $n$ is omitted and the word actually said is liars" (Cruttenden 2013: 5).

24 Np. Batala's ASMR. W jednym ze swoich filmów artystka wyjaśnia różnicę: https://www. youtube.com/watch?v=RwqWBvSmvzw [data dostępu: 3.02.2019]. 


\subsection{Dźwięki niewerbalne}

Druga zasadnicza grupa wyzwalaczy akustycznych to dźwięki niewerbalne, czyli dźwięki nieprodukowane przez aparat artykulacyjny. Zbiór ten obejmuje mnóstwo różnych typów dźwięków, które opisywane są w filmach ASMR ze względu na towarzyszącą im czynność. Wymieniam podstawowe:

- głośne oddychanie/wydychanie (ang. breathing)

- lizanie ucha (ang. ear licking)

- jedzenie ucha (ang. ear eating)

- masaż uszu (ang. ear massage)

- czyszczenie uszu (ang. ear cleaning)

- "dźwięki rąk" - pocieranie (ang. hand sounds)

- trzepotanie palcami (ang. finger fluttering)

- stukanie/opukiwanie (szybkie i wolne, agresywne i delikatne; ang. tapping)

- szeleszczenie (ang. crinkling)

- drapanie (ang. scratching)

- rysowanie (ang. drawing)

- pisanie (ang. writing)

- pisanie na klawiaturze (ang. typing)

- przewracanie kartek (ang. page flipping)

- ugniatanie/ściskanie miękkich przedmiotów, np. gąbki (ang. soft objects squeezing)

- pędzelkowanie mikrofonu (ang. mic brushing)

- drapanie mikrofonu (ang. mic scratching)

- rozpylanie sprayu (ang. spraying)

- tybetańskie misy dźwiękowe

- muzyka relaksacyjna

Trzy pierwsze znajdują się na granicy kategorii DŹWIĘKI APARATU ARTYKULACYJNEGO i DŹWIĘKI POZAWERBALNE, bowiem $w$ ich produkcji biorą udział narządy mowy. Zaliczam je jednak do kategorii drugiej, ponieważ w przypadku oddychania mamy do czynienia z prymarną funkcją organizmu, a towarzyszący jej dźwięk jest efektem sekundarnym, a w przypadku lizania i jedzenia ucha dźwięki produkowane są nie przez same narządy mowy, ale poprzez ich kontakt $\mathrm{z}$ innym przedmiotem. Artyści używają $\mathrm{w}$ tym celu wyspecjalizowanych binauralnych mikrofonów ${ }^{25}$ ze specjalnymi nakładkami w kształcie uszu (Ryc. 2):

25 Więcej na temat kwestii technicznych - vide koniec sekcji 2.3. 


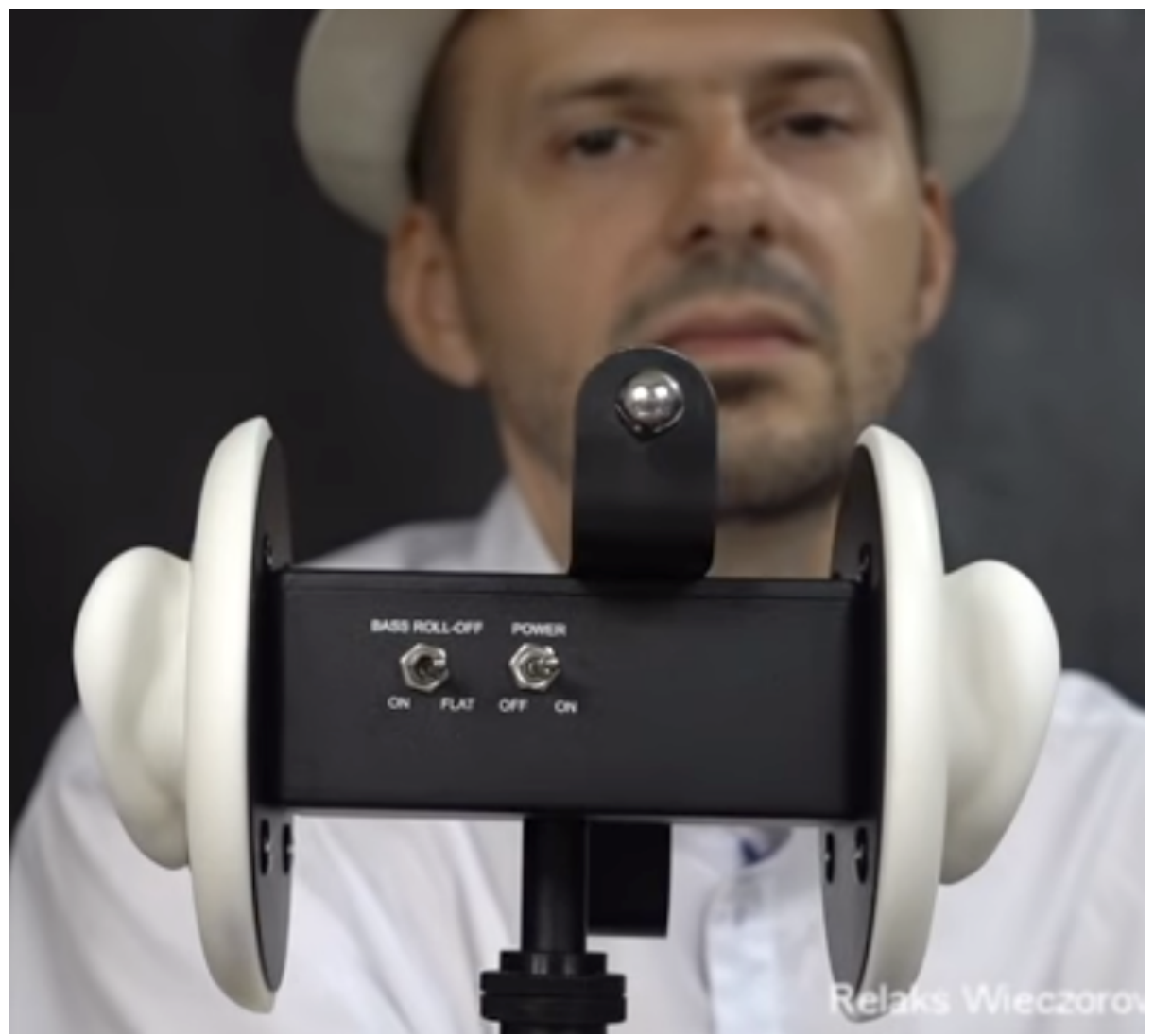

Ryc. 2. Mikrofon binauralny z nakładkami w kształcie ucha ${ }^{26}$

Źródło: opracowanie własne.

Mikrofony binauralne dają możliwość generowania dźwięków od ucha do ucha z bliskiej odległości (ang. close-up ear to ear, np. GibiASMR "[ASMR] Close-Up Ear-to-Ear Positive Affirmations | For Anxiety, Sleep"27).

Odbiorcy filmów ASMR mają różne preferencje dźwiękowe. Ze względu na to powstają filmiki, które łączą mowę z dźwiękami niewerbalnymi, np. stukanie, któremu towarzyszy szept, ale także filmiki, które są tagowane jako NO TALKING. Wówczas wykonywanie wymienionych wyżej czynności jest jedynym źródłem dźwięku w nagraniu.

26 Przyjemne dreszcze mózgu - Relaks Wieczorową Porą (ASMR po polsku) https://www. youtube.com/watch?v=QzI_czljDoE [data dostępu: 17.04.2019].

27 https://www.youtube.com/watch?v=pdE2Yws3MD4 [data dostępu: 20.02.2019]. 
Ponieważ wiele $\mathrm{z}$ tych czynności wywołuje różne dźwięki w zależności od obiektu, na którym są wykonywane, osobną kategorię stanowią tzw. przedmioty ASMR. Na przykład, jeżeli nagranie poświęcone jest odgłosom stukania, opukiwania, artysta próbuje zróżnicować dźwięki nie tylko poprzez tempo i natężenie dźwięku, ale także poprzez dobór przedmiotów, w które stuka. Mogą to być pudełeczka, opakowania, buteleczki z płynem, przedmioty metalowe, drewniane, itp. Niektóre artystki stukają we własne zęby (np. Chynaunique $A S M R$ „ASMR Teeth Tapping”28), paznokciami o paznokcie/tipsami o tipsy (np. ASMR blossom „ASMR - Tapping on Nails [Most Underrated Trigger]"29), a jedna $\mathrm{z}$ artystek przykleja specjalne naklejki $3 \mathrm{D}$ na twarz i relaksuje odbiorców stukaniem w owe naklejki (Batala's ASMR „ASMR 3D Sticker Tapping | (Tingle Overload) "30; Ryc. 3)

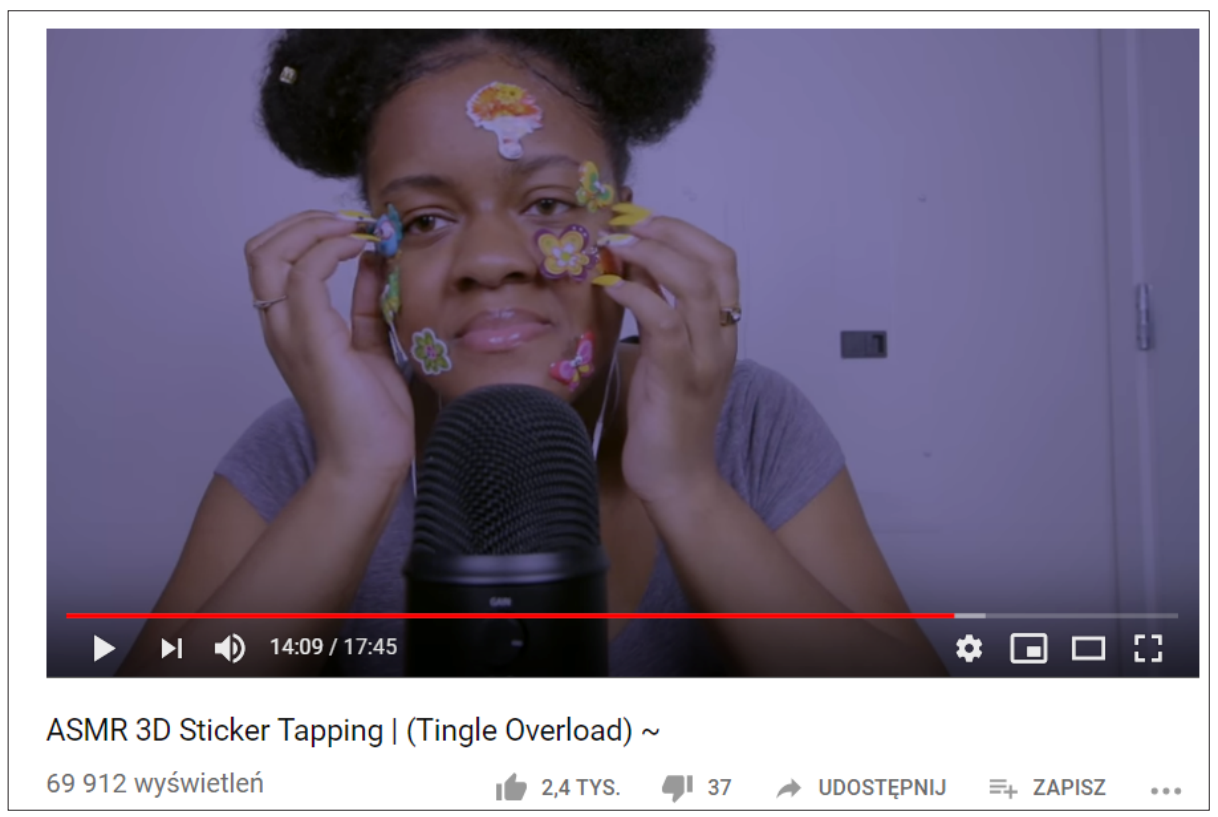

Ryc. 3. Dźwięki niewerbalne. Stukanie w naklejki (face stickers).

Źródło: opracowanie własne.

Inne przedmioty często wykorzystywane $\mathrm{w}$ nagraniach ASMR to pałeczki, patyczki, pędzelki (do malowania, makijażu), gąbeczki, klocuszki (drewniane, plastykowe), piórka, widelce silikonowe, narzędzia, szczoteczki, itd. Wiele z nich

\footnotetext{
$28 \mathrm{https} / / /$ www.youtube.com/watch? $v=e g U V t m H V x Z 8$ [data dostępu: 3.02.2019].

29 https://www.youtube.com/watch?v=Gl7qw_OcvX4 [data dostępu: 7.02.2019].

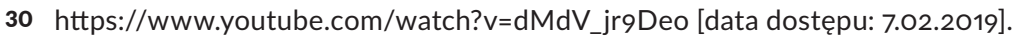


wiąże się ze specyficznym typem filmu ASMR, który omówiony jest w sekcji 3), a mianowicie z odgrywaniem ról (ang. role-plays) np. rękawiczki gumowe, stetoskop (role-play: wizyta lekarska), błyszczyk do ust role-play: makijaż), nożyczki, szczotka, grzebień (role-play: wizyta u fryzjera). Jeden z najbardziej znanych polskich artystów - Adrian Biskup alias Relaks Wieczorowa Pora (ASMR po polsku $)^{31}$ - wyprodukował specjalny role-play „Sprzedawca Przedmiocików ASMR - Odgrywanie Roli PL"32, w którym pokazuje przedmioty używane w swoich filmach i opisuje ich właściwości dźwiękowe.

Istotną kwestią dla wielu odbiorców jest technologia - jakiego sprzętu używa artysta, jakiej jakości są jego filmy. Filmy wysokiej jakości dźwięku i obrazu cieszą się rzecz jasna dużą popularnością, jednakże dla niektórych słuchaczy efekt ASMR wywołują filmy low-fi, czyli nagrania o niskiej wierności dźwięku (np. Tena ASMR „ASMR Lo-Fi Personal Attention | Face Touching \& Positive Affirmations"33), o które specjalnie proszą artystów. Niejednokrotnie artyści eksperymentują ze swoim wysokiej klasy sprzętem, próbując różnych ustawień i prosząc słuchaczy o ocenę jakości filmu/dźwięku w komentarzach. Nie oznacza to oczywiście, że wszyscy artyści ASMR używają kosztownych urządzeń i że jest to aspekt decydujący o popularności kanału. Wielu artystów korzysta ze zwykłego iPhone’a oraz zestawu słuchawkowego z mikrofonem.

\subsection{Wyzwalacze wizualne}

Wyzwalacze oddziałujące poprzez zmysł wzroku dzielą się na trzy kategorie: światło, kolor i ruch. Dla niektórych odbiorców już sama sceneria ma olbrzymie znaczenie - na przykład poziom jasności tła, przedmioty znajdujące się w otoczeniu artysty. Podstawowym wyzwalaczem świetlnym jest latarka (ang. flashlight), którą artysta wodzi przed kamerą, zmieniając kąt padania światła. Najczęściej używane jest światło białe, ale stosowane są również światła kolorowe. Innym wyzwalaczem świetlnym są lampki o różnych kolorach i kształtach, np. lampki sensoryczne typu lava lamp (np. doveASMR „Lava Lamp ASMR [Male Whisper] feat. unintelligble whispering, tapping, crinkling"34), lampki choinkowe, itd. Kolorem artyści działają na różne sposoby - najczęściej poprzez pokazywanie różnobarwnych przedmiotów i pomalowane paznokcie lub kolorowe tipsy; np. artystka Brittany ASMR w nagraniu „ASMR My Crystal Collection. MEGA Wet Mouth

31 Artysta prowadzi także kanał w języku angielskim SensorAdi ASMR, http://sensoradi.com [data dostępu: 7.05.2019].

32 https://www.youtube.com/watch?v=q9BtBRIQMEo [data dostępu: 6.04.2019].

33 https://www.youtube.com/watch?v=NYRW5FyDRIk [data dostępu: 28.03.2019].

$34 \mathrm{https} / /$ www.youtube.com/watch?v=vOPokRszA2E [data dostępu: 9.04.2019]. 
Sounds, Fake Eating Sounds, Tapping, Whisper, Soft Spoken"35 pokazuje swoją złożoną z kilkudziesięciu egzemplarzy kolekcję kryształów o różnych kształtach i barwach, stukając w nie pomalowanymi na kolor indygo paznokciami (Ryc. 4). Komentarze pod filmem ${ }^{36}$ pokazują, iż odbiorcy wychwycili te elementy jako istotne (np. ddrew1973: Holy crap, magic nails! lol; B Elise: Loveeee the bright blue nails!!!; Astrix: I love crystals. Also that coating is definitely a part of the shell on your fossils. The finish is kind of described being like abalone which is really beautiful on (sic!) my opinion. Or like Aurora Borealis ${ }^{37}$ ).

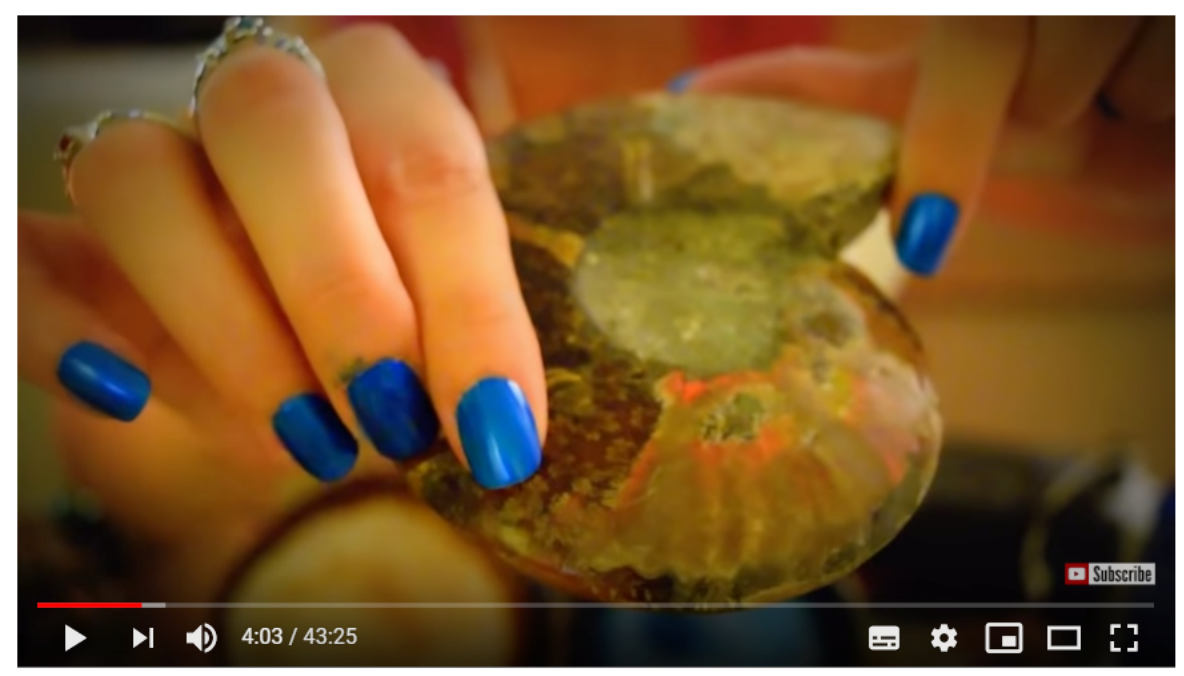

ASMR My Crystal Collection. MEGA Wet Mouth Sounds, Fake Eating Sounds, Tapping, Whisper, Soft Spoken

Ryc. 4. Kolor jako wyzwalacz wizualny ${ }^{\mathbf{3 8}}$.

Źródło: opracowanie własne.

Najpopularniejszymi wyzwalaczami w zakresie ruchu są ruchy rąk (ang. hand movements), pędzelkowanie twarzy (ang. face brushing) oraz tzw. tracing (wodzenie, śledzenie - najczęściej palcem). Obok tego należą tutaj wszystkie ruchy związane

35 https://www.youtube.com/watch?v=6fzZgeiulMc [data dostępu: 6.12.2018].

36 https://www.youtube.com/watch?v=6fzZgeiulMc [data dostępu: 6.12.2018].

37 ddrew1973: O kurde, magiczne paznokcie! lol; B Elise: Koooocham te jaskrawoniebieskie paznokcie!!!; Astrix: Kocham kryształy. A ta powłoka jest z pewnościa częścia muszli na twoich skamielinach. Wykończenie to coś w rodzaju ucha morskiego, co moim zdaniem jest naprawdę piękne. Lub jak zorza polarna; tłum. moje, K. O.

https://www.youtube.com/watch?v=6fzZqeiulMc [data dostępu: 6.12.2018]. 
z czynnościami wynikającymi z odgrywanej przez artystę roli w filmikach typu role-play - cięcie nożyczkami, pisanie, rysowanie, nakładanie kosmetyków na twarz, masaż głowy i ciała, wykonywanie origami, itp.

Filmy z wyzwalaczami wizualnymi w czystej formie tworzone są przez artystów bardzo rzadko. ASMR Alysaa nazywa swój film "VISUALS ONLY ASMR Challenge - Can you get Tingles From this NO SOUND Video? Un Reto"39 wyzwaniem, co wynika z założenia, że większość nagrań ASMR łączy bodźce wizualne z dźwiękowymi. Najczęściej wyzwalacze wizualne towarzyszą dźwiękowym na dwa sposoby: (1) nie są z nimi powiązane tematycznie - dotyczy to przede wszystkim ruchów rąk i pędzelkowania (artysta najczęściej tworzy film mówiony, w którym owe bodźce wizualne są komponentem niezależnym, paralelnym w stosunku do mowy), lub (2) wynikają z odgrywanej roli, np. wodzenie latarką przy odgrywaniu roli „badanie neurologiczne/badanie nerwów czaszkowych" (ang. cranical nerve examination)" lub strzyżenie nożyczkami w roli „wizyta u fryzjera”.

\section{Role-play i personal attention jako supra-wyzwalacze}

Zaproponowana powyżej klasyfikacja (sekcja 2.1., Ryc. 1) nie uwzględnia dwóch rodzajów bodźców. Nazywam je supra-wyzwalaczami, ponieważ nie chodzi w nich jedynie o oddziaływanie na odbiorcę poprzez kanały zmysłowe i dobór odpowiednich efektów dźwiękowych i wizualnych, ale o sposób nawiązywania i utrzymywania kontaktu z odbiorcą na poziomie globalnej struktury komunikacji ze słuchaczem, co samo w sobie działa jak wyzwalacz/czynnik relaksacyjny.

Pierwszym z nich jest personal attention. Polscy artyści nagrywający filmy tego typu bądź zachowują w deskrypcji oryginalną angielską nazwę bądź tłumaczą ją jako osobista uwaga, co nie jest najtrafniejszym wyborem translatorskim ze względu zarówno na sens tej frazy jak i na jej warstwę stylistyczną. Bliższym ekwiwalentem tej kolokacji byłoby w moim przekonaniu słowo atencja, które występuje we współczesnym języku polskim jako anglosemantyzm (por. Witalisz 2007: 134), bowiem przyswoiło z języka angielskiego nowe znacznie „okazywanie komuś uwagi, zainteresowania”. Wyzwalacz ów działa w ten sposób, że okazywanie odbiorcy zainteresowania poprzez personalizowanie wypowiedzi - traktowanie odbiorcy jak gdyby filmik był adresowany do niego osobiście, mówienie do niego, głaskanie - samo w sobie wywołuje bądź efekt ASMR bądź uczucie odprężenia.

Drugim supra-wyzwalaczem jest wspominane już wcześniej odgrywanie roli. Ten sposób działania na odbiorcę wykorzystuje cały wachlarz przedmiotów ASMR 
oraz bodźców sonicznych i wzrokowych, których dobór warunkowany jest przede wszystkim tematycznie. Oto lista często nagrywanych role-play'ów:

- badanie nerwów czaszkowych (wzrok, słuch, węch, ang. cranial nerve examination)

- wizyta u lekarza

- makijaż

- aplikacja błyszczyków do ust (ang. lip-gloss application)

- malowanie paznokci

- fryzjer

- masaż głowy

- masaż twarzy

- troskliwy przyjaciel (ang. caring friend)

- rozpakowywanie i testowanie urządzeń i innych przedmiotów (ang. unboxing)

- sprzedawca

- pokazywanie kolekcji (ang. show and tell)

- pokazywanie zakupionych przedmiotów określonej kategorii (ang. haul, np. make-up haul)

- medytacja

- trening autogenny Schultza

- sposób na migrenę (ang. migraine relief), itd.

Oczywiście artyści, by wyjść poza ramy schematu i przyciągnąć więcej odbiorców, tworzą role-play'e o przeróżnej, czasami zaskakującej tematyce, np. artysta IamCyr: rola seryjnego mordercy „Serial Killer Victim Role Play (Cringey ASMR)"40, artystka Karuna Satori ASMR: lunch w latach osiemdziesiątych „ASMR Lunch In The 8os | Your Best Friends Diner"41, rosyjski artysta ASMRex: kompletownie apteczki pierwszej pomocy „ACMP на русском - Ролевая игра „Медицинская аптечка” [ спокойная речь | шелесты | шорохи ] \#6о"42.

Specyfika role-play polega na tym, że artysta oddziałuje na odbiorcę poprzez quasi-dialog, poprzez traktowanie go jako obecnego „tu i teraz” w konwersacji, poprzez zadawanie mu pytań, traktowanie go jako swojego jedynego wyselekcjowanego interlokutora, którego oczekiwania mają zostać spełnione (Jak się dzisiaj czujesz? zbadam twoje oczy, zrobię ci makijaż, ostrzyge Twoje włosy, Jaka fryzurę wybierasz? itd.), co skutkuje budowaniem określonej przestrzeni dyskursywnej (patrz sekcja 5).

$40 \mathrm{https}: / /$ www.youtube.com/watch?v=d4hMipqGpYo [data dostępu: 17.09.2018].

$41 \mathrm{https}: / /$ www.youtube.com/watch?v=bi8wo64l57U [data dostępu: 17.09.2018].

$42 \mathrm{https} / / /$ www.youtube.com/watch?v=ISFQIOFnU5Q\&list=PLsT5FG3O_umngEvul7KEZDVwlo zYM7Bej\&index=15 [data dostępu: 20.09.2018]. 


\section{Medioonomastyka - nazwy kanałów ASMR}

Jak już wspominałem zjawisko ASMR ucieleśniło się w przestrzeni wirtualnej. Funkcjonuje ono w niej w ten sposób, że artyści ASMR posiadają swoje kanały - przede wszystkim w serwisie youtube, ale także na platformie crowdfundingowej Patreon, za której pośrednictwem za zamieszczane treści artyści pozyskują fundusze ${ }^{43}$. Artyści, subskrybenci i inni odbiorcy kanałów tworzą tzw. społeczność ASMR (ang. ASMR community). Są kanały ASMR, które posiadają nawet ponad milion subskrybentów, np. Gentle Whispering ASMR subskrybuje 1681132 osób ${ }^{44}$. Na swoich kanałach artyści zamieszczają filmy ASMR lub (rzadziej) nagrania audio, pod którymi słuchacze mogą dodawać publiczne komentarze. Obok gotowych nagrań artyści prowadzą także transmisje na żywo, tzw. livéy/livestreamy, podczas których dyskusja pomiędzy odbiorcami i artystą przebiega w czasie rzeczywistym $^{45}$. Niektórzy artyści podejmują współpracę i tworzą nagrania wspólnie, tzw. collab, np. Relaxing Male ASMR i Tyson ASMR ${ }^{46}$.

$\mathrm{W}$ ostatnich latach wraz z rozwojem Internetu w onomastyce wyodrębniła się nowa subdziedzina - medioonomastyka, która zajmuje się „opisem - klasyfikacją, charakterystyką i oceną normatywną - zbioru nazw funkcjonujących współcześnie w przestrzeni cybernetyczno-medialnej." (Rutkowski 2016: 172). Jej jednostkami są medionimy, do których należą, jako rodzaj chrematonimów, nazwy kanałów ASMR. W społeczności ASMR nazwy kanałów często funkcjonują z jednej strony jako rodzaj autoreklamy ${ }^{47}$, z drugiej - jako rodzaj autocharakterystyki (por. Naruszewicz-Duchlińska 2015: 427-436) - określiłbym fuzję tych funkcji jako autoprezentację, bowiem owe nazwy, będąc źródłem informacji o artyście, mają jednocześnie zachęcić odbiorcę do słuchania, oglądania, „lajkowania” i subskrybowania. Obok tych funkcji (informacyjnej i pragmatycznej) nazwy kanałów ASMR odzwierciedlają także pewne aspekty konceptualizacji rzeczywistości ASMR z perspektywy twórców.

W toku badania sporządzona została lista 131 kanałów ASMR, które podzielona została na 17 kategorii w zależności od tego, jaki aspekt funkcjonalny/znaczeniowy/

43 Zwykle filmy zamieszczane na Patreonie są dłuższe, posiadają lepszą jakość i należą do kategorii custom videos.

$44 \mathrm{https} / / /$ www.youtube.com/results?search_query=asmr+gentle+whispering [data dostępu: 9.05.2019].

45 Więcej na ten temat w sekcji 5.

46 "ASMR Collab With Relaxing Male ASMR - Interesting Random Facts - Sleep Inducing Male Whisper": https://www.youtube.com/watch?v=CSG4zWx34Gk [data dostępu: 9.05.2019]. Komunikacja pomiędzy artystami w obrębie nagrania stanowi interesujący odrębny problem badawczy.

47 Por. badania nad pseudonimami internetowymi A. Naruszewicz-Duchlińskiej (2003: 88): „Nick może być swoistą autoreklamą swego nosiciela i kreatora, informując o jego walorach i zachęcając do nawiązania z nim kontaktu". 
językowy profilowany jest przez nazwę kanału (Tab. 1). Lista zawiera 115 nazw

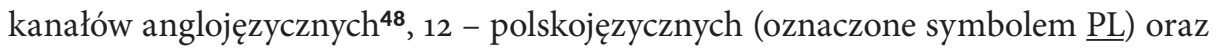

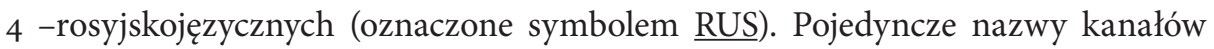
mogłyby zostać włączone do dwóch kategorii, np. Cosmic Tingles - do kategorii (6) i (8), JustAWhisperingGuy - do kategorii (8) i (9), Relaxing Male ASMR - do kategorii (5) i (9), TheWaterwhispers - do kategorii (8) i (14). Decyzja o zaliczeniu ich do danej klasy dokonana została w oparciu o wartość profilującą komponentów medionimu, np. w przypadku Relaxing Male ASMR za wartość dominującą uznano identyfikację płci. W klasyfikacji nie uwzględniona została graficzna reprezentacja medionimów, czyli sposób ich zapisu, np. „3” zamiast „e” w nazwie „Th3HazySea”. Kolejność grup warunkowana jest wyłącznie czynnikami technicznymi (rozmiarem tabeli).

Tabela. 1. Rzeczywistość ASMR odzwierciedlona w medionimach.

\begin{tabular}{|l|l|l|}
\hline poziomie gramatyki & 4) nomina lenitatis & (5) cisza/spokój/sen/relaks \\
TranquiLily ASMR & accidentallygraceful & Audible Quiet \\
TingleTastic & DeesSofterSide & CJ \& Chill \\
Tinglesaurus Rex & Feather Jo & Hushed Life ASMR \\
ASMRex (RUS) & Gentle Asmr & PeacefulMindASMR ASMR \\
Hailey Whispering Rose & GentleWhispering & peacefulslumber ASMR \\
TingleYouToSleep AMSR & Heather Feather & QueenOfSerene \\
Asmring & Mellow ASMR & QuietBiscuit \\
letmeASMRit & mysilkysounds & Relaxing Music \\
\hline (2) rodzaj wyzwalacza & Slight Sounds & Relaxingsounds \\
taptap:asmr & (Soft ASMR & Sensually Serene \\
Mouth Sounds & Softly Sharry & ThePeacefulWhisper \\
Drops ASMR & softlygaloshes & Relaks Wieczorową Porą (PL) \\
& SoftlyRelax & CichoSza ASMR (PL) \\
& softlywhispered & Silentia ASMR (PL) \\
& softsoundwhispers & Po cichutku, na paluszkach \\
& ASMR (PL) \\
\hline
\end{tabular}

48 W niektórych wypadkach twórcy produkują filmy w różnych językach, np. artysta Paris ASMR, który jest rodzimym użytkownikiem języka francuskiego, nagrywa filmy po angielsku, po francusku i po niemiecku. 


\begin{tabular}{|c|c|c|}
\hline $\begin{array}{l}\text { (3) ASMR jako sztuka/ } \\
\text { rozrywka } \\
\text { Paul Artwork } \\
\text { sOUNDsculptures } \\
\text { The ASMR Circus } \\
\text { Victorias Tingly Funland } \\
\text { VIZZION ASMRtainment }\end{array}$ & $\begin{array}{l}\text { SoftSugarClouds } \\
\text { The Most Gentle Sounds } \\
\text { SoftAnnaPL (PL) } \\
\text { SubtleSounds ASMR }\end{array}$ & $\begin{array}{l}\text { poCichu ASMR (PL) } \\
\text { RelaxRob } \\
\text { SleepyHeadC ASMR } \\
\text { PJ Dreams ASMR }\end{array}$ \\
\hline 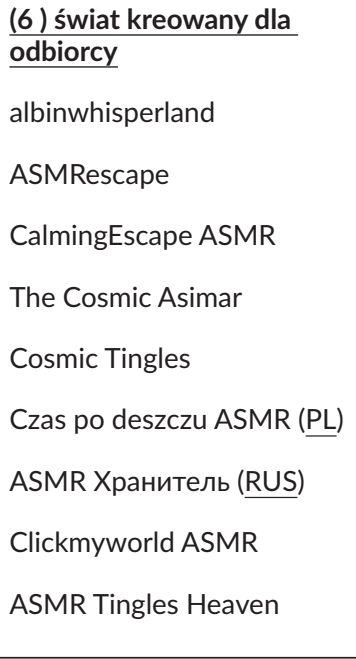 & $\begin{array}{l}\text { (7) role-plays/tematyka } \\
\text { nagrań } \\
\text { ASMR Therapist } \\
\text { ASMR Barber } \\
\text { MassageASMR } \\
\text { PsycheTruth massage } \\
\text { MedicalASMR } \\
\text { HolisticTreatments360 } \\
\text { SWITCHSCISSORS } \\
\text { ACMP PeцenTb œ ASMR } \\
\text { Cooking (RUS) } \\
\text { POLISHNOTES (PL) }\end{array}$ & $\begin{array}{l}\text { (8) szept } \\
\text { AuroraWhispers } \\
\text { chelseamorganwhispers } \\
\text { DollyWhispers } \\
\text { Moon Sunwhisper } \\
\text { ReadingWhispers } \\
\text { sweetwhispers4u } \\
\text { The Curly Whisperer } \\
\text { Szepcząca w sieci (PL) } \\
\text { Lily Whispers ASMR }\end{array}$ \\
\hline $\begin{array}{l}\text { (9) Typ postaci artysty/ } \\
\text { identyfikacja } \\
\text { Shinobi } \\
\text { Rapunzel ASMR } \\
\text { BlackMaleASMR } \\
\text { Relaxing Male ASMR } \\
\text { A Random Guy ASMR } \\
\text { JustAWhisperingGuy }\end{array}$ & $\begin{array}{l}\underline{\text { (10) lokalizacja }} \\
\text { Northern Whisper } \\
\text { SiberianBeauty } \\
\text { TheSwedishSnowflake } \\
\text { Whitewinterwhispers } \\
\text { SouthernASMR Sounds } \\
\text { PARIS ASMR }\end{array}$ & $\begin{array}{l}\text { (11) ciarki/zmysły } \\
\text { Brain Tingles } \\
\text { TingleBell Asmr } \\
\text { TouchingTingles } \\
\text { Late Night Tingles ASMR } \\
\text { Tingting ASMR }\end{array}$ \\
\hline $\begin{array}{l}\text { (12) religijne } \\
\text { TruthStudyASMR } \\
\text { ASMR Psalter } \\
\text { spirit.filled.tascam } \\
\text { Glory ASMR }\end{array}$ & $\begin{array}{l}\text { (14) metafora dźwięku/myśli/ } \\
\text { etc. } \\
\text { Deep Ocean of Sounds } \\
\text { DeepThought } \\
\text { Ephemeral Rift } \\
\text { MissMindBuzz } \\
\text { TheAbysswalker } \\
\text { Th3HazySea }\end{array}$ & $\begin{array}{l}\text { (15) Synestezja } \\
\text { WhisperingHands4You } \\
\text { WhisperingLight } \\
\text { WhispersparklesASMR } \\
\text { The Starlight Whisper }\end{array}$ \\
\hline
\end{tabular}




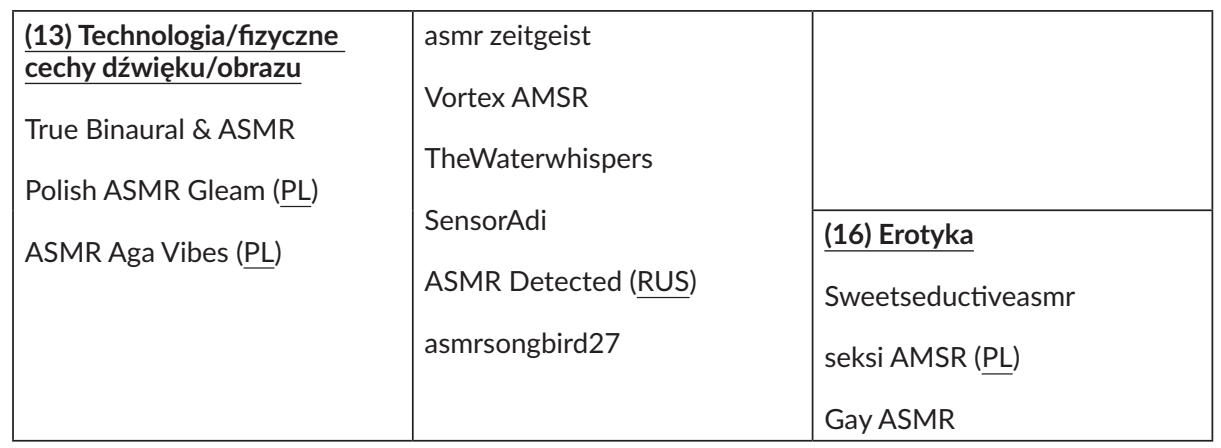

Źródło: opracowanie własne.

W Tabeli 1 nie zostały uwzględnione medionimy, które zaliczyłem do odrębnej kategorii (17), fundowane wyłącznie na imieniu lub pseudonimie artysty, np. ahska ASMR (PL), czy Tyson ASMR, gdyż nie są one czytelne z perspektywy konotacji. Wiele z nich ma w świecie ASMR wartość marki, bowiem cieszą się ogromną popularnością w społeczności ASMR, np. GibiASMR, asmr zeitgeist, ASMR Karuna Satori i Brittany ASMR, które mają odpowiednio - 1925957 (prawie 2 miliony!), 1117 881, 733 696, 109340 subskrypcji. Przyjrzyjmy się bliżej pozostałym kategoriom.

Grupa (1) zawiera medionimy stworzone w oparciu o gry słowotwórcze. Cztery z nich stanowią blendy ${ }^{49}$ : TranquiLily ASMR stanowi niedokładny blend (tranqulity + Lilly), TingleTastic - to kontaminacja Tingle+fantastic w oparciu o analogię do Runtastic ${ }^{\mathrm{TM}}$, ASMRex (RUS) to blend (zarówno z perspektywy wymowy angielskiej [eresema:re/I/əks], jak i rosyjskiej [aesemereks]): ASMR+Rex (czyli król ASMR). Tinglesaurus Rex to także król, tym razem ciarek - medionim ten stanowi złożenie (Tingle+saurus) oparte na analogii do nazw popularnych gatunków dinozaurów. Hailey Whispering Rose jest nazwą, której jednoreferencyjną strukturę imienia i nazwiska rozbija leksem whispering, co stanowi nie tylko czynnik autoprezentacyjny, ale także grę słów wynikającą z prioprialnego charakteru nazwiska (whispering rose - szepcząca róża). Pozostałe trzy nazwy fundowane są na konwersji: w nazwie kanału TingleYouToSleep AMSR rzeczownik tingle ulega werbalizacji - staje się czasownikiem (dosł. WyciarkujęCięDoSnu ${ }^{50}$ ), w medionimie letmeASMRit podobnemu procesowi ulega sam skrótowiec ASMR (dosł. pozwólmitozaesemerowć), a ostatnia nazwa Asmring jest rezultatem dwóch procesów - werbalizacji: rzeczownik ASMR staje się czasownikiem to asmr (dosł. aesemerować), który z kolei ulega kolejnemu procesowi - wtórnej nominalizacji - i staje się

49 Definicja blendu (kontaminacji) patrz: Szymanek (1998: 99-100).

50 tłum. moje, K. O. - decyzja o prefiksacji w tłumaczeniu wynika z rezultatywnego charakteru frazy „będę ciarkował tak długo, aż zapadniesz w sen”. Wszystkie zastosowane w analizie tłumaczenia medionimów są mojego autorstwa. 
rzeczownikiem odczasownikowym (gerundium/nomen actionis): asmring (dosł. aesemerowanie).

Grupy (2), (7), (8), (11) i (13) profilują - wyprowadzają na pierwszy plan - określone fasety z całego układu sceny ASMR ${ }^{51}$. Grupy (2) i (8) wskazują na rodzaj wyzwalacza. W pierwszej z nich profilowane są: opukiwanie, dźwięki ust, krople, a w drugiej - szept, któremu w przypadku ReadingWhispers towarzyszy dodatkowa charakterystyka realizacji wyzwalacza. Grupa (7) wyodrębnia typ odgrywanej roli lub tematykę nagrań: terapeuta, fryzjer, fryzjer męski/golibroda, masaż, medycyna, leczenie/terapie holistyczne, kulinaria, notatki ${ }^{52}$. Dla grupy (11) składnikiem bazowym są ciarki (tingles), opatrzone w trzech przypadkach odpowiednimi atrybutami - ciarki mózgu (Brain Tingles), ciarki w połączeniu ze zmysłem dotyku (TouchingTingles), ciarki późną nocą (Late Night Tingles). Nazwa Tingting ASMR stworzona jest w oparciu o dwa zabiegi słowotwórcze - ucięcie (clipping; por. Grzegorczykowa et al. 1999: 364) oraz reduplikację, która odzwierciedla typ wyzwalacza (por. sekcja 2.2.1.), a medionim TingleBell Asmr stanowi fonetyczną grę słów w odniesieniu do nazwy postaci z bajki „Piotruś Pan”: Tinker Bell (pol. Dzwoneczek), co stawia go na granicy kategorii (11) i (9). Grupa (13) wyodrębnia technologiczne i fizyczne atrybuty dźwięku lub obrazu - binauralność (True Binaural \& ASMR), blask/poświatę (Polish ASMR Gleam) oraz źródło powstawania fal dźwiękowych - wibracje (ASMR Aga Vibes; $\mathrm{z}$ ang. vibes = vibrations).

W grupach (4) i (5) podstawę nazwy stanowią określenia, które naturalnie wynikają z celu ASMR. W grupie czwartej są to leksemy konotujące łagodność i delikatność (nomina lenitatis): z gracją (graceful), miękki/cichy, delikatny - w stopniu równym i wyższym oraz $\mathrm{w}$ wariancie przysłówkowym (soft, softer, softly), piórko (feather) $)^{53}$, delikatny - w stopniu równym i najwyższym (gentle, most gentle),

51 Terminy profilowanie, układ sceny stosowane są w rozumieniu Langackerowskim (Langacker 1991: 5-7).

52 Nazwa kanału POLISHNOTES nie jest do końca przejrzysta, dopiero opis kanału i zamieszczone na nim nagrania informują, iż chodzi o tematykę organizacji pracy w trakcie studiów - sporządzania notatek, itp. Nazwa ta podchodzi także pod kategorię (10) - lokalizacja, gdyż wskazuje na narodowość artystki.

53 Ciekawym onimem w grupie (4) jest Heather Feather, bowiem nie tylko zawiera w sobie prioprialny pseudonim o znaczeniu piórko, ale istnieje prawdopodobieństwo, iż nawiązuje także do postaci z podręcznika do fonetyki pt. „How now brown cow?” (Ponsonby 1987: 4849), w którym każdy z rozdziałów poświęcony jest odrębnemu dźwiękowi w języku angielskim. Po drylach wprowadzających w strukturze każdego rozdziału znajduje się tekst, którego istota polega na tym, że praktycznie każdy z użytych w nim wyrazów zawiera ćwiczony w tym rozdziale dźwięk. Bohaterką tekstu poświęconego dźwiękowi [ð] jest Heather Feather ['heðə 'feðə], a innym istotnym dźwiękiem dla obu członów nazwy jest dźwięk [e], który w języku angielskim jest dźwiękiem wąskim, krótkim, figuratywnie ujmując „lekkim”, zatem jego charakter wpisuje się w profilowane w omawianej grupie cechy. 
łagodny/miękki/aksamitny (mellow), jedwabisty (silky), lekkie [dźwięki] (slight [sounds]), płatek śniegu (snowflake), subtelne [dźwięki] (subtle [sounds]). Z kolei w grupie piątej znajdują się leksemy nazywające ciszę, spokój, sen i relaks lub wywołujące związane z nimi asocjacje: spokój (quiet), spokój/relaks (chill), spokojny (peaceful, serene), lekki sen (slumber), senny (sleepy), sny/marzenia/marzenia senne (dreams) wyciszony (hushed; hush - wyraz dźwiękonaśladowczy, którego polski ekwiwalent to cicho! sza!), relaksacyjny/relaksujący (relaxing), relaks, cicho sza, po cichu, po cichutku, na paluszkach, cisza (łac. pl. silentia). Interesująca jest w tej grupie nazwa z substantywizowanym przymiotnikiem QueenOfSerene, która, podobnie jak w przypadku omówionych w kategorii (1) onimów ASMRex i Tinglesaurus Rex, wyraża aksjologiczne profilowanie postaci: królowa spokoju).

Medionimy z grupy (3), (6) i (14) fundowane są na metaforach. W grupie (3) świat ASMR opisywany jest jako świat sztuki lub rozrywki: szata graficzna (artwork), rzeźby dźwięków (sound sculptures), cyrk (circus), lunapark (funland). Nazwa ASMRtainment stanowi niedokładną kontaminację ASMR + entertainment (rozrywka), dlatego przynależy także do klasy (1). W grupie (6) nazwy kanałów pomyślane zostały jako wykładniki kreowania swoistego świata lub przestrzeni dla odbiorców, co odzwierciedlają takie leksemy jak kraina [szeptów] (whisperland), [uspokajająca] ucieczka ([calming] escape), kosmiczny (cosmic), czas po deszczu, świat (world), niebo [ciarek] ([tingles] heaven). Ciekawą metaforą jest rosyjski nomen actionis ASMR Хранитель, bowiem ASMR jawi się w jej świetle jako przestrzeń, która wymaga troski (хранитель to protektor, obrońca, stróż). Grupa (14) zawiera onimy, będące rezultatem różnego typu metaforyzacji - dany kanał ASMR to: głęboki ocean dźwięków (Deep Ocean of Sounds), głęboka myśl (Deep Thought), ulotna rozpadlina (metafora jest nieprzejrzysta, opis kanału ${ }^{54}$ sugeruje, że owa szczelina/rozpadlina stanowi drogę chwilowej ucieczki od rzeczywistości życia codziennego), gwar w umyśle (mind buzz), otchłań (abyss; artysta kreuje się na spacerującego w otchłani - TheAbysswalker), mgliste morze (hazy sea), duch czasu (Zeitgeist), wir (vortex), woda (wodne szepty, water whispers), [śpiew] słowika

54 „Rozpoczęcie działalności 9/2011, możecie uważać ten kanał za przedłużenie mnie samego. Jestem niezależnym, domorosłym samoukiem à la 'siedem fachów ósma bieda', podobnym do szalonego naukowca pracującego w podziemnym laboratorium, tworząc unikatowe mikstury złożone z różnorakich składników takich jak ASMR, sztuka, relaksacja, przyroda, komedia (surrealistyczna, satyryczna, parodia, z użyciem rekwizytów, oparta o grę słów, etc.), filozofia (absurdyzm, cynizm, optymizm, egzystencjalizm, nihilizm, anarchizm, ateizm i in.), doświadczenia życiowe oraz wiele innych eksperymentów, wiele z nich nieortodoksyjnych i dających do myślenia, ale przede wszystkim z celem dostarczenia pewnej formy rozrywki lub ucieczki od jakże często stresującego, zapracowanego, poddawanego nieustannym testom życia (podkreślenie moje, K. O., tłum. moje, K. O.); https://www.youtube.com/user/ EphemeralRift/about [data dostępu: 11.05.2019]. 
(songbird). Dwie ostatnie nazwy w tej kategorii są metaforą zdolności do wykrywania zmysłów, przez które doświadczane jest ASMR (sensor to czujnik) i wykrywania samoistnej odpowiedzi meridianów czuciowych jako takiej (ASMR Detected - ASMR wykryte).

Grupa (9) zawiera onimy identyfikujące - wskazujące na związek artysty z postacią ze świata folkloru czy fantastyki: shinobi to inna nazwa wojowników ninja, a Rapunzel to imię głównej bohaterki niemieckiej baśni ludowej o tym samym tytule, a także jej współczesnej animowanej adaptacji (pol. Roszpunka) lub wskazujące na pewne aspekty tożsamości artysty: wszystkie cztery nazwy: BlackMaleASMR, Relaxing Male ASMR, A Random Guy ASMR i JustAWhisperingGuy zawierają identyfikację płci (male - męski, guy - facet), a jedna z nich dodatkowo identyfikację antropologicznej odmiany człowieka (black - odmiana czarna) ${ }^{55}$.

Do grupy (10) należą nazwy o charakterze referencyjnym - w sposób mniej lub bardziej dokładny lokalizują miejsce zamieszkania artysty. Najdokładniejszą wartość lokalizującą wykazuje wchodzący w skład nazwy toponim Paris (Paryż); następnie onim TheSwedishSnowflake (Swedish - szwedzki), który pozwala zidentyfikować narodowość artysty. Jeszcze mniej precyzyjna jest wskazująca jedynie na ogromną krainę geograficzną nazwa - SiberianBeauty (Siberian - syberyjski). Northern Whisper i SouthernASMR Sounds wskazują jedynie na kierunki świata i dopiero opis kanału ujawnia, iż w pierwszym przypadku chodzi o Norwegię (północ jako kraje skandynawskie), a w drugim o południe Stanów Zjednoczonych (opis ujawnia również, że chodzi o fonetyczny aspekt nagrań: „Będę zamieszczać na kanale filmy ASMR z południowym akcentem, ..." ${ }^{56}$. Nieprecyzyjna jest również nazwa Whitewinterwhispers, która może wskazywać na kraje, w których panuje zima (opis kanału i drugi język filmów ujawniają, iż artystka pochodzi z Finlandii).

Nazwy kanałów z grupy (12) odzwierciedlają ich religijną tematykę. Zawarte w nich słowa i wyrażenia: studia nad prawdą (truth study), Psałterz (Psalter), napełniona duchem (spirit filled), chwała (glory) są nośnikami konotacji związanych z wiarą. Potwierdzają to opisy filmów i kanałów, np. spirit.filled.tascam daje następujący komentarz do jednego ze swoich nagrań: „Jeżeli jest to pierwsze moje wideo, które oglądasz, należę do kościoła apostolskiego i tworzę te nagrania by połączyć moją miłość do ASMR z moją miłością do Jezusa w nadziei, że pomoże ci to w zasypianiu i złagodzi twoje zmartwienia ${ }^{57}$ (tłum. moje, K. O.)

55 Identyfikacja płci biologicznej jest oczywista w przypadku, gdy nazwa kanału zawiera typowe imię męskie lub żeńskie.

56 https://www.youtube.com/channel/UCpw8ZudbxklOi73pWel6s9A/about [data dostępu: 4.05.2019], (tłum. moje, K. O.).

57 https://www.youtube.com/watch?v=ckTHGdoWikg [data dostępu: 7.05.2019]. 
Bardzo ciekawą kategorię stanowi grupa (15), ponieważ zawarte w niej nazwy fundowane są w oparciu o synestezję, a konkretnie w oparciu o powiązanie zmysłu słuchu ze zmysłem wzroku: szept (whisper) łączy się tutaj z ruchem rąk (whispering hands) i światłem (light - światło, sparkles - iskry, starlight - światło gwiazdy).

Grupa (16) to nazwy kanałów, których treści budzą spore kontrowersje w środowisku ASMR, bowiem większość osób doświadczających efektu ASMR uważa, że nie ma on nic wspólnego z doznaniami natury seksualnej (vide przypis 3: „...to coś jak srebrzysta iskra przenikająca moja głowę i mózg... prawie jak coś w rodzaju orgazmu głowy, ale nie ma to nic wspólnego z doznaniami seksualnymi...”) ${ }^{58}$. Rezultaty analizy przedstawione w cytowanym wcześniej artykule Barratt i Davisa (2015: Results) wskazują, że 5\% badanych używa nagrań ASMR do stymulacji seksualnej, podczas gdy ogromna większość badanych (84\%) jest przeciwna łączeniu sfery ASMR z erotyką.

\section{Dyskursywne wyznaczniki twórczości ASMR}

W ramach analizy dyskursu ASMR na pierwszy plan wysuwają się dwa jego aspekty. Po pierwsze funkcja fatyczna i socjalizująca (Grzegorczykowa 2010: 50-51, 55) budujące więź w obrębie społeczności ASMR, których realizacja leży po stronie artysty ASMR, a po drugie - funkcja ewaluatywna i perswazyjna ${ }^{59}$, które realizowane są przez odbiorców nagrań.

Artyści zacieśniają więzi z odbiorcami poprzez po pierwsze personalizację komunikacji, co czynią przede wszystkim w filmach typu role-play i personal attention. Jak wspominałem, $\mathrm{w}$ tego typu filmach artysta prowadzi pozorną konwersację z odbiorcą, zwraca się do niego w ten sposób, jak gdyby komunikacja z nim przebiegała w rzeczywistości i bliskości - stwarza iluzję realnego kontaktu z odbiorcą. Poprzez swoje wypowiedzi próbuje zniwelować dystans i wykreować sytuację komunikacyjną, w której obaj uczestnicy kontaktują się bezpośrednio - bez użycia medium internetowego. Na przykład w nagraniu " $8<$ Sleep-inducing Haircut ASMR | Shampoo | Page Flipping | Scissors” na kanale Gentle Whispering $A S M R$ przedstawia się to $\mathrm{w}$ następujący sposób (podkreślone zostały frazy, personalizujące komunikację) ${ }^{60}$ :

- wprowadzenie iluzji komunikacji bezpośredniej:

Cześć, witaj w moim salonie fryzjerskim. ${ }^{61}$

(Hi, welcome to my hair salon.)

58 Por. "Co to jest ASMR? Dla kogo? Po co? ASMR po polsku PL” na kanale Relaks wieczorowa pora, min. 4.35-5.50.

59 Por. emotywno-oceniające oraz nakłaniające akty mowy (Awdiejew 2004: 115-129, 134).

$60 \mathrm{https} / / /$ www.youtube.com/watch?v=gf_MqDBBMPI [data dostępu: 30.04.2019].

61 Wszystkie poniższe tłumaczenia moje, K. O. 
- postawienie „ty” w centrum uwagi; czas ciągły profiluje duratywność - utrzymywanie kontaktu z odbiorcą:

Będe sie dzisiaj toba zajmowała.

(I'm going to be taking care of you.)

- zmniejszenie dystansu fizycznego:

Obiecuję, że będę ostrożna.

(I promise that I'll be careful.)

- zdefiniowanie aktywnej roli odbiorcy (artysta przyjmuje rolę pasywną - słuchacza, a odbiorcy zostaje stworzona przestrzeń do zwerbalizowania swoich oczekiwań):

... i będe stuchała Twoich życzeń...

(... and that I'll listen to your wishes...)

- akomodacja - dostosowanie się do potrzeb odbiorcy:

...i wystylizuje jedynie taka fryzure, w której be dzie Ci do twarzy...

(... and only create the style that is going to be flattering on you...)

- ewaluatywny akt mowy: pochwała - pozytywna ocena działań odbiorcy

(por. Awdiejew 1987: 120-124):

O! Świetna robota! [w zakresie dbania o swoje włosy]

(Oh, you're doing great job!)

- komplementowanie ${ }^{62}$ o wysokim wysyceniu aksjologicznym - metafora fundowana na leksemie angel (anielski), wielki kwantyfikator - anything (wszystko, cokolwiek), przymiotnik oceniający good (pol. przysłówek: dobrze), komisyw ${ }^{63}$ I promise! (Obiecuję!), modalizator ewaluatywny (operator interakcyjny) just (po prostu), superlativus - the sweetest thing (przeurocza):

Szczerze mówiąc, $z$ twoja anielska twarza wszystko bẹdzie wygladać dobrze. Obiecuje! !

(To be honest with your angel face anything will look good,_I promise!)

Jesteś po prostu przeurocza!

(You're just the sweetest thing!)

Artyści personalizują kontakt ze słuchaczami także poprzez filmy $Q \mho A$ - (pytania i odpowiedzi, ang. Questions and Answers) oraz livestreamy (transmisje na żywo).

62 Por. strategie komplementowania opisane w monografii B. Drabik (2004).

63 W terminologii Searle'a (1999: 234-235). 
Nagrania Q\&A bazują bądź na gotowych dostępnych w Internecie ankietach bądź - o wiele częściej - na pytaniach, kierowanych przez słuchaczy do artysty. Artysta zapowiada wcześniej plan realizacji filmu Q\&A, zachęcając odbiorców do przesyłania pytań (np. via instagram), na które odpowiada w trakcie filmu. Pytania są różnej natury - od neutralnych np. Co cię skłonito do robienia filmów ASMR? Skąd takie zainteresowanie? Jaki jest twój ulubiony artysta ASMR, twój ulubiony dźwięk ASMR?64, poprzez osobiste, np. Ile masz lat? (How old are you?) Ile masz wzrostu? (How tall are you?) Czym się martwisz? (What are you worried about?) ${ }^{65}$, aż po wkraczające w strefę intymności - dotyczące sfery seksualnej. Niektórzy artyści w tych kwestiach wypowiadają się otwarcie ${ }^{66}$, a niektórzy stawiają granice personalizacji, np. Tyson ASMR w video pt. „ASMR - 10,00o Subscriber Q\&A - Whispered (1 Hour)” mówi: Dostałem mnóstwo pytań dotyczacych sfery seksualnej, ale raczej nie odpowiem na nie wszystkie. (I got a lot of sexual question which I probably won't answer all of them) ${ }^{67}$.

Transmisjesąformąkontaktunajbardziejzbliżonego do kontaktubezpośredniego, ponieważ artysta prowadzi dialog z odbiorcami w czasie rzeczywistym on-line - dialog ów stanowi połączenie komunikacji pisemnej i ustnej, ponieważ słuchacze komunikują się z artystą na bieżąco, pisząc komentarze widoczne w tzw. oknie czatu, a twórca reaguje/odpowiada na nie w formie ustnej (Ryc. 5).
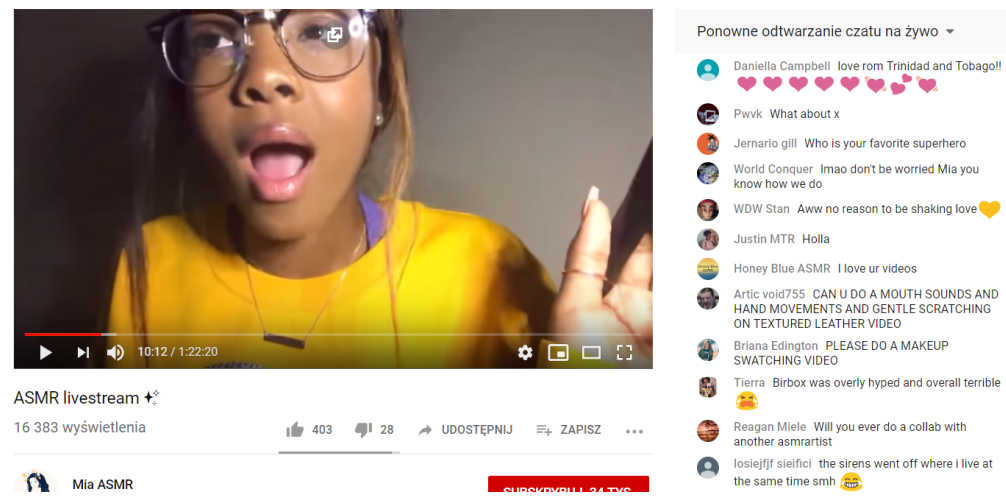

Ryc. 5. Mia ASMR livestream ${ }^{68}$.

Źródło: opracowanie własne

64 ashka ASMR PL "ASMR*Q\&A*1000 subskrybcji!*whisper*PL" min. 1.25-1.43 https://www. youtube.com/watch?v=425f6iRn60E [data dostępu: 13.09.2018].

65 Relaxing Male ASMR "ASMR 20k Q\&A and Ramble - Relaxing Male ASMR Whispered" https:// www.youtube.com/watch?v=GPOSbD2yqeA [data dostępu: 30.04.2019].

$66 \mathrm{np}$. Slim Whispers „ASMR Q\&A (Sexuality,Cuts etc)”, https://www.youtube.com/ watch?v=oYrE89TiLuA [data dostępu: 29.11.2018].

$67 \mathrm{https}: / /$ www.youtube.com/watch?v=jCC6ifD1YwM [data dostępu: 12.12.2018].

$68 \mathrm{https} / / / w w w . y o u t u b e . c o m / w a t c h ? v=6 \mathrm{D} 53 T c w a T s c$ [data dostępu: 4.05.2019]. Artyści w większości przypadków zapisują swoje transmisje, które można potem wraz z czatem odtworzyć „na żywo”. 
Oczywiście na czacie nieraz pojawiają się wypowiedzi nierelewantne, np. World Conquer podczas transmisji na kanale Mia ASMR pisze bez związku/odniesienia: my girlfriend don't like me calling her princess (moja dziewczyna nie lubi, kiedy nazywam ją księżniczka, patrz także Ryc. 5. - okno czatu), ale wiele z nich stanowi próbę rzeczywistego nawiązania kontaktu z artystą. Nie na wszystkie wypowiedzi artysta jest zawsze w stanie zareagować. Uzależnione jest to od liczby osób biorących udział w czacie. Oto kilka przykładów komunikacji podczas transmisji z polskiego kanału Czas po deszczu 69 (pisownia oryginalna, z pominięciem emotikonów; transkrypcja ustnych odpowiedzi artystów moja, K. O.):

Cloperflejk Jeste stresik na lajwie?

Sue Aihara Uf zdążyłam :D

Małgorzata Piłat jestem! jeszcze $w$ tramwaju ale czatowalam $z$ telefonem od 1omin

Young Gamers Team pozdrowisz

Odpowiedź artysty: Young Gamers Team, oczywiście, pozdrawiam serdecznie!

Weronika S Dobry wieczór Bou!

Odpowiedź artysty: Dobry wieczór, Weroniko!

paulas Game NAGRAJ ROLEPLAY FRYZJER

Odpowiedź artysty: paulas Game - z role-play'em fryzjera to jest tak, że, wiecie, tak $w$ zasadzie to jest tego bardzo dużo na sieci, a ja szukam takich tematów, które... których nie chciałbym tak bardzo mocno powielać, więc jeżeli robić fryzjera, to na jakiśswój własny odmienny sposób i zastanawiałem się nad tym, ale generalnie tego typu role-play'e trzeba czuć, bo nie ma nic gorszego, kiedy nie czujemy tematu i na siłe staramy się ten temat zrobić. Jest to zupełnie bez sensu. Takich materiałów nie chciatbym, żebyście zobaczyli u mnie na kanale i... pewnie nie zobaczycie. To znaczy, nie chodzi o ten temat, tylko takich, które ja wewnętrznie nie będę czut i będę nagrywat na site, tak więc tego nie chciatbym robić.

Drugim sposobem budowania więzi z odbiorcami jest nadawanie grupie swoich słuchaczy wyjątkowego statusu, co realizowane jest fatycznie w tzw. intro do filmu.

$69 \mathrm{https}: / /$ www.youtube.com/watch?v=xZiHsaT4Jow [data dostępu: 8.05.2019]. 
Artysta rozpoczyna film od stałej frazy - przywitania z odbiorcami - która jest nie tylko jego znakiem rozpoznawczym, ale ma także charakter afiliacyjny ${ }^{70}$, bowiem wzbudza w słuchaczu poczucie przynależności do społeczności kanału poprzez zawarte $\mathrm{w}$ niej wyrażenia o pozytywnym ładunku aksjologicznym (rodzina, bratnie dusze, moje życie, mój świat), np.

- Slight Sounds ASMR ${ }^{71}$ :

Witajcie moje „dźwiękowe bratnie dusze”.

Hello my "sound soulmates".

- Karuna Satori ASMR72:

Cześć, tu Karuna Satori! Witam wszystkich na naszym kanale, a jeśli jesteś tu nowy, witaj w rodzinie!

Hello, Karuna Satori here! Welcome to our channel everybody and if you are new here, welcome to the family!

- Batala's ASMR ${ }^{73}$ :

Witajcie moje jaskierki, moje życie, moja rodzino, mój świecie! ${ }^{74}$

Hello my buttercups, my life, my family $\underline{\text { my worldddddd! }}$

We wspomnianych już komentarzach do filmów oraz dyskusji na czatach podczas livestreamów odbiorcy realizują funkcję perswazyjną i ewaluatywną, czyli zjednej strony werbalizują swoje oczekiwania wobec artysty, a z drugiej strony oceniają kanał i twórcę zarówno z perspektywy personalnej, jak i z perspektywy profesjonalnej. Przyjrzyjmy się wybranym wypowiedziom i sposobie w jaki zostały sformułowane:

- Oczekiwania odbiorców (perswazja)

- polski kanal Czas po deszczu: ${ }^{75}$

KokosiQ Czekam z niecierpliwością na szkolenie IMDA

- polski kana1: Relaks wieczorowa pora: $7^{76}$

Bartek pisanie na kartce

\footnotetext{
70 Por. definicje afiliacji w: Chudzicka (1998: 61).

71 https://www.youtube.com/watch?v=IXdj9|rH2l8 [data dostępu: 2.04.2019].

$72 \mathrm{https} / / /$ www.youtube.com/watch? $\mathrm{v}=\mathrm{QHM}-6 \mathrm{P} 8 \mathrm{NIWU}$ [data dostępu: 16.02.2019].

73 https://www.youtube.com/watch?v=3zgxAEuT10M [data dostępu: 28.03.2019].

$74 \mathrm{~W}$ oryginale angielskim następuje zachowanie dźwięczności i reduplikacja spółgłoski [d] w wygłosie.

75 https://www.youtube.com/watch?v=xZiHsaT4Jow [data dostępu: 8.05.2019].

76 https://www.youtube.com/watch?v=bQ8ci7yYqlQ [data dostępu: 7.05.2019].
} 
Uran pisanie drewnem po drewnie mikołaj bobowski Błagam Cie weź gąbeczke teraz

Chris Nudzęsię może Pan trochę bardziej „stymulować” (lol nie wiem jak to nazwać) prawa stronę?

- kanał: Mia ASMR: ${ }^{77}$

Danika Salorio Czy możesz powiedzieć moje imię?! (Can you say my name please ?!)

Artic void755 Mia proszę zrób delikatne drapanie i stukanie na skórze perforowanej

(Mia Please do a gentle scratching and tapping on textured leather)

Reagan Miele Czy mogłabyś zrobić swój codzienny makijaż proszę!!

(Could you do a makeup routine please!!)

Honey Blue ASMR Czy możesz napisać (palcem przed kamerą) moje imię? (Can u trace my name?)

Funkcja perswazyjna dotyczy tutaj - typu wyzwalacza (np. tracing), sposobu realizacji (np. stymulowanie prawej strony), role-play (np. szkolenie, makijaż) lub wywołania personalizacji kontaktu ze strony nadawcy (prośba o wypowiedzenie imienia). Jest ona realizowana przez całą gamę form dyrektywnych: niebezpośrednich - opisowych (czekam z niecierpliwością na), nominatywnych (pisanie na kartce), interrogatywnych (może Pan, can you, could you) oraz bezpośrednich - wykładników predykatów prośby (błagam, proszę) oraz trybu rozkazującego (zrób, weź) ${ }^{\mathbf{7 8}}$.

- wypowiedzi ewaluatywne:

\section{- ad personam}

kanał: Mia ASMR: ${ }^{79}$

Raelin Maple Co to za rozświetlacz?? Wyglada na tobie cholernie słodko (Which highlighter is that?? Looks hella cute on you)

RCH 32 Będę Twoim chłopakiem (ill be your boyfriend)

S.T. A.T Jesteś piękna! (You're Beautiful!)

\section{Kanał: Relaxing Male ASMR:80}

Christian Ada On jest taki przystojny! To powinna być zbrodnia sama w sobie!! (He's too damned Handsome!!! That should be a crime within itself!!)

\footnotetext{
$77 \mathrm{https}$ //www.youtube.com/watch?v=6D53TcwaTsc [data dostępu: 4.05.2019].

78 Por. definicje i klasyfikacje dyrektywnych aktów mowy w Komorowska (2008: 24-40)

79 https://www.youtube.com/watch?v=6D53TcwaTsc [data dostępu: 4.05.2019].

80 https://www.youtube.com/watch?v=iFlpyR3cHHo [data dostępu: 10.05.2019].
} 


\section{- dotyczące nagrania} kanal: Mia ASMR: ${ }^{81}$

S.T. A.T Świetna zawartość! Tak trzymaj! (... Keep Up The Great Content!...)

Myrian BI Niezmiennie kocham twoje niestyszalne szepty. Nigdy się nimi nie znudzę. (always love your inaudible whispering. Inever get tired of it.)

\section{Kanał: Relaxing Male ASMR:82}

Ricky Leyva

Już sam sposób, w jaki patrzysz na kamerę powoduje, że chce mi się spać. Wiem, ze twoje nagrania maja świetne audio, ale aspekty wizualne sa równie dobre. (The way you look at the camera makes me want to fall asleep all on it's own. I know your vids have great audio but the visual aspects are really just as good.)

Trevor

Mam nadzieję, że zdajesz sobie sprawe jak ważne sa twoje nagrania dla osób, które maja kłopoty ze spaniem. Sen jest tak ważny, ale dla niektórych $z$ nas noc jest czasem największej walki. Wkładasz w swoje nagrania tyle pracy i to widać i one napraaawdę pomagaja. (I hope you realize how important your videos are for those of us who really struggle with sleep. sleep is so important but for some of us night time is our biggest battle. you put so much work into them and it shows and they are sooo helpful. thank you.)

Komentarze słuchaczy obfitują w mnóstwo innych aspektów, np. dystansowanie się - mówienie o artyście w osobie trzeciej (Tierra: Ona chodzi do college’u (She's in college), zadawanie pytań: (Mariono Griffin: Uprawiasz jakiś sport? (You play any sports?) ${ }^{83}$, opisywanie tego, co doświadczają, odtwarzając nagrania (Nikki G: Czuje ciarki na kręgosłupie, poczawszy od prawego ucha, w kierunku szyi i w dót pleców. A potem dreszcze rozładowuja napięcie (My spine is tingling starting from my right ear, to my neck and down my back. Then I shiver out the tension ${ }^{84}$ ) itd. Ponadto komunikacja ta ma charakter wielokodowy (por. Kress and van Leeuwen 2006, 8-9), ponieważ użytkownicy stosują emotikony. Jak widać, całościowe opracowanie dyskursu ASMR w ramach komunikacji na linii odbiorcy-artysta stanowi obszerne pole badawcze i wymaga odrębnego opracowania.

\footnotetext{
81 https://www.youtube.com/watch?v=6D53TcwaTsc [data dostępu: 4.05.2019].

82 https://www.youtube.com/watch?v=iFlpyR3cHHo [data dostępu: 10.05.2019].

83 Mia ASMR https://www.youtube.com/watch?v=6D53TcwaTsc [data dostępu: 4.05.2019].

84 https://www.youtube.com/watch?v=iFlpyR3cHHo [data dostępu: 10.05.2019].
} 


\section{Uwagi końcowe}

Wychodząc poza ramy lingwistyki chciałbym zwrócić uwagę na trzy zagrożenia wynikające z medium, przez które ASMR jest odbierane, a jest to najczęściej telefon komórkowy lub podobnego typu urządzenie. Po pierwsze, urządzenia te generują światło niebieskie, na które ekspozycja jest szkodliwa dla ludzkiego oka: „promieniowanie światła niebieskiego jako czynnik fototoksyczny może prowadzić do poważnego uszkodzenia siatkówki ludzkiego oka." (Hill-Bator, Pyziak 2015: 143), zatem częste oglądanie filmów ASMR - koncentracja na wyzwalaczach wizualnych - może mieć negatywne skutki oftalmologiczne. Po drugie, wielu współczesnych socjologów i pedagogów ostrzega, że „wirtualny świat staje się specyficzną alternatywą życia społecznego, zastępuje bowiem kontakty z bliskimi” (Kołomyjski 2013: 256). W przypadku budowania więzi społecznej i emocjonalnej, którą opisałem jedynie z perspektywy dyskursu, istnieje obawa, iż poszukiwanie doznań związanych z ASMR może zaburzyć potrzebę kontaktu w świecie rzeczywistym. W komentarzu do filmu na kanale Relaxing Male ASMR „Helping You Fall Asleep - Whispers, Music, Breathing, Hugs", którego jednym z komponentów jest wirtualne przytulanie (ang. hugs), odbiorca Ash V. pisze: „Kocham, kiedy włączasz przytulanie do swoich nagrań, powoduje to, że mam poczucie bezpieczeństwa i opieki, ponieważ nie doświadczam zbyt wiele bliskiej relacji/interakcji w prawdziwym życiu"85. I po trzecie, ponieważ cyberprzestrzeń jako taka stanowi pole do rozwoju uzależnień, również $\mathrm{w}$ tym przypadku należy liczyć się z ich potencjalnym wystąpieniem. Nie przeprowadzono w tym zakresie badań, lecz można znaleźć następujące wpisy na forach internetowych: „Bardzo niepokoję się z powodu mojego uzależnienia od ASMR. Dosłownie, za każdym razem, kiedy chcę coś zrobić, myślę o ASMR. Przestaję przez to grać w gry, odrabiać zadania domowe i zajmować się swoim życiem"\$6. Wielu odbiorców ASMR regularnie odtwarza nagrania ASMR w charakterze remedium na bezsenność, a ta sfera pozostawia sporą przestrzeń dla tego typu zagrożeń.

Wymienione zagrożenia wynikają nie $\mathrm{z}$ samej istoty zjawiska, ale z cyberprzestrzeni, w której się ono rozwija. Samo w sobie jest ono zjawiskiem pozytywnym. Doświadczanie efektu ASMR, relaksacja, redukcja stresu, facylitacja zasypiania to namacalne korzyści płynące z tego zjawiska. ASMR jest fenomenem wieloaspektowym, który może być badany z różnych perspektyw - medycznej,

\footnotetext{
85 „I always love when you include hugs in your videos; it makes me feel safe and cared for since I don't get much close interaction in real life"; https://www.youtube.com/ watch?v=iFlpyR3cHHo [data dostępu 6.05.2019].

86 „I'm Seriously Worried About My ASMR Addiction. Literally, everytime I want to do something I think of ASMR. It stops me from playing my games, doing homework and getting on with my life". (tłum. na polski moje, K. O.) https://steamcommunity.com/discussions/ forum/12/494631967662059809 [data dostępu: 9.05.2019].
} 
neurobiologicznej, psychologicznej, socjologicznej, a także - co próbowałem przybliżyć - językoznawczej. Powstaje coraz więcej kanałów ASMR, a liczba subskrybentów rośnie, co otwiera dla badacza szerokie spektrum empiryczne.

\section{Bibliografia}

Ahuja A., Ahuja N.K., „Clinical Role-Play in Autonomous Sensory Meridian Response (ASMR) Videos Performance and Placebo in the Digital Era”, JAMA 2019, nr 321(14), s. 1336-1337, https://doi.org/10.1001/jama.2019.2302

Ahuja N.K., "It feels good to be measured': clinical role-play, Walker Percy, and the tingles", Perspectives in Biology and Medicine 2013, nr 56(3), s. 442-451, https:// doi.org/10.1353/pbm.2013.0022

Awdiejew A., Gramatyka interakcji werbalnej, Kraków 2004.

Awdiejew A., Pragmatyczne podstawy interpretacji wypowiedzeń, Kraków 1987.

Barratt E.L., Davis N.J., „Autonomous Sensory Meridian Response (ASMR): a flow-like mental state", PeerJ 32015 , e851, https://doi.org/10.7717/peerj.851

Chudzicka A., „Potrzeba afiliacji i otrzymywane wsparcie społeczne u osób bezrobotnych", Chowanna 1998, nr 1, s. 60-68.

Cruttenden A., Gimson's Pronunciation of English, London and New York 2013.

Drabik B., Komplement $i$ komplementowanie jako akt mowy i komunikacyjna strategia, Kraków 2004.

Fredborg B., Clark J., Smith S.D., „An Examination of Personality Traits Associated with Autonomous Sensory Meridian Response (ASMR)", Front. Psychol., 23.02.2017, 8:247, https://doi.org/10.3389/fpsyg.2017.00247201

Garro D., „Autonomous Meridian Sensory Response - from Internet subculture to audiovisual therapy", [w:] Proceedings of the Electronic Visualisation and the Art Conference, 2017, s. 395-402, https://dx.doi.org/10.14236/ewic/EVA2017.79

Grzegorczykowa R., Wstęp do językoznawstwa, Warszawa 2010.

Grzegorczykowa R. et. al., Gramatyka wspótczesnego języka polskiego: morfologia, Warszawa 1999.

Gut M., Marchewka A., „Funkcjonalny rezonans magnetyczny - nieinwazyjna metoda obrazowania aktywności ludzkiego mózgu”, [w:] Konferencja „Nowe metody w neurobiologii", Warszawa 2004, s. 35-40.

Harpaz Y., Levkovitz Y., Lavidor M., „Lexical ambiguity resolution in Wernicke's area and its right homologue", Cortex 2009, nr 45(9), s. 1097-1103.

Hill-Bator A., Pyziak A., „Znaczenie filtra światła niebieskiego w soczewkach wewnątrzgałkowych stosowanych w chirurgii zaćmy", Ophtatherapy 2015, nr 2(2), s. 143-147. 
Janik McErlean A.B., Banissy M.J., „Assessing Individual Variation in Personality and Empathy Traits in Self-Reported Autonomous Sensory Meridian Response", Multisensory Research 2017, nr 30(6), https://doi.org/10.1163/22134808-00002571 Knill Ch., Dotyk i komunikacja. Wyd. 2 zm., Warszawa 2009.

Kołomyjski D., „Fenomen zabijania w grach komputerowych”, [w:] Człowiek w świecie rzeczywistym $i$ wirtualnym. Wybrane patologie społeczno-wychowawcze w cyberprzestrzeni, red. A. Andrzejewska, J. Bednarek, S. Ćmiel, Józefów 2013, s. 251-263.

Komorowska E., Pragmatyka dyrektywnych aktów mowy w języku polskim, Szczecin-Rostock 2008.

Kress G., van Leeuwen T., Reading Images: The Grammar of Visual Design, $2^{\text {nd }}$ ed. London-New York 2006.

Langacker R., Concept, image, and symbol. The cognitive basis of grammar, BerlinNew York 1991.

Lochte B.C., Guillory S.A., Richard C.A.H., Kelley W.H., „An fMRI investigation of the neural correlates underlying the autonomous sensory meridian response (ASMR)", Bioimpacts 2018, nr 8(4), s. 295-304.

Naruszewicz-Duchlińska A., „Pseudonimy internetowe (nicknames) jako forma autoreklamy”, Prace Językoznawcze 2003, nr 5, s. 85-98.

Naruszewicz-Duchlińska A., „Pseudonimy internetowe (nicknames) jako forma autocharakterystyki", [w:] Funkcje nazw własnych w kulturze i komunikacji, red. I. Sarnowska-Giefing, M. Balowski, M. Graf, Poznań 2015, s. 427-436.

Needham J. et al., Science and Civilisation in China. Vol. VI: Biology and Biological Technology. Part 6: Medicine, Ch. Cullen (red.), Cambridge 2004.

Ponsonby M., How now brown cow? A course in the pronunciation of English with exercises and dialogues, New York-London-Toronto-Sydney-Tokyo-Singapore 1987.

Richard C., Brain Tingles: The Secret to Triggering Autonomous Sensory Meridian Response for Improved Sleep, Stress Relief, and Head-to-Toe Euphoria, Avon MA: Adams Media 2019.

Rogowska A., „U źródeł synestezji: podstawy fizjologiczne i funkcjonalne”, Przegląd Psychologiczny 2002, nr 45(4), s. 465-474.

Rutkowski M., „Medioonomastyka w ramach mediolingwistyki”, Prace Językoznawcze 2016, nr 18(3), s. 171-180.

Searle J. R., Umyst - język - społeczeństwo. Filozofia i rzeczywistość, Warszawa 1999.

Smith N., Snider A.-M., „ASMR, affect and digitally-mediated intimacy”, Emotion, Space and Society 2019, t. 30, s. 41-48, https://doi.org/10.1016/j.emospa.2018.11.002

Smith S.D., Fredborg B.K., Kornelsen J., „An examination of the default mode network in individuals with autonomous sensory meridian response (ASMR)", Social Neuroscience 2017, nr 12(4), s. 361-365. 
Szymanek B., Introduction to morphological analysis, Warszawa 1998.

Williams P.G., Johnson K.T., Curtis B.J., King J.B., Anderson, J.S., „Individual differences in aesthetic engagement are reflected in resting-state fMRI connectivity: Implications for stress resilience", NeuroImage 2018, t. 179, s. 156-165, https://doi. org/10.1016/j.neuroimage.2018.06.042

Wiśniewski M., Zarys fonetyki ifonologii współczesnego języka polskiego, Toruń 2001. Witalisz A., Anglosemantyzmy w języku polskim - ze słownikiem. Kraków 2007.

Krzysztof Ozga

\title{
Tajemnice ASMR - perspektywa ogólna i lingwistyczna
}

\author{
Streszczenie
}

Artykuł prezentuje zjawisko ASMR (Autonomous Sensory Meridian Response, tłum. pol. samoistna odpowiedź meridianów czuciowych) z perspektywy ogólnej i lingwistycznej. Definicja pojęcia i zreferowanie stanu badań stanowią wprowadzenie do klasyfikacji wyzwalaczy ASMR ze względu na zmysły stanowiące źródło doświadczania tzw. efektu ASMR. Autor przedstawia argumenty za włączeniem dotyku i zapachu do klasyfikacji wyzwalaczy. Lingwistyczna analiza zjawiska koncentruje się wokół fonetycznych właściwości wyzwalaczy głosowych, aspektów onomastycznych - analiza gramatyczna i konceptualna wyodrębnionych 17 klas medionimów (nazw kanałów ASMR) oraz dyskursu jako przestrzeni, w której realizowane są funkcje - fatyczna i socjalizująca (budujące więź w obrębie społeczności ASMR; ich realizacja leży po stronie artysty ASMR) oraz ewaluatywna i perswazyjna (ich realizacja leży po stronie odbiorców nagrań).

Słowa kluczowe: ASMR, neurobiologia, zmysły, synestezja, fonetyka, onomastyka, medionimy, konceptualizacja, dyskurs, funkcje języka. 


\title{
The secrets of ASMR - a general and a linguistic perspective
}

\author{
Summary
}

The article presents the concept of ASMR (Autonomous Sensory Meridian Response) from a general and a linguistic perspective. The definition of the notion and a review on the state of research is followed by a classification of ASMR triggers based on the senses which constitute the source of experiencing the ASMR effect. The author argues that touch and smell be included in the classification of the triggers. The linguistic analysis focuses on the following issues: the phonetic properties of the voice triggers, onomastics - a grammatical and conceptual study of the 17 classes of medionyms (names of ASMR channels) which were distinguished in the present research, and the ASMR discourse as the space where phatic and social functions are carried out on the part of ASMRtists as factors developing bonds within the ASMR community and where evaluative and persuasive functions are prominent in the comments of the recipients.

Keywords: ASMR, neurobiology, senses, synesthesia, phonetics, onomastics, medionym, conceptualisation, discourse, language functions

Krzysztof Ozga - doktor nauk humanistycznych w zakresie językoznawstwa, specjalności: językoznawstwo ogólne, lingwistyka matematyczna, filologia rosyjska, filologia angielska. Adiunkt w Zakładzie Językoznawstwa Rosyjskiego w Instytucie Filologii Wschodniosłowiańskiej UJ. Jego zainteresowania naukowe, zorientowane na zagadnienia językoznawstwa współczesnego zarówno w aspekcie teoretycznym jak i praktycznym, koncentrują się wokół problemów z zakresu składni semantycznej, semantyki i pragmatyki, gramatyki komunikacyjnej, językoznawstwa kognitywnego, teorii tekstu i dyskursu, lingwistycznych teorii przekładu, tekstów wielokodowych oraz komunikacji interpersonalnej. Autor książki On Isomorphism and Non-Isomorphism in Language, Łódź 2011. Współredaktor serii „Język i metoda. Język rosyjski w badaniach lingwistycznych XXI wieku”. Mediator stały wpisany na listę Prezesa Sądu Okręgowego w Krakowie. 